\title{
Covid-19 Küresel Salgınının Uluslararası Ticarete Etkileri
} (Araştırma Makalesi)

\author{
The Impact of Covid-19 Pandemic on International Trade
}

Doi: 10.29023/alanyaakademik.816057

\section{Ercan TAŞKIN}

Prof. Dr., Kütahya Dumlupınar Üniversitesi, İktisadi ve İdari Bilimler Fakültesi,

Uluslararası Ticaret ve Finansman Bölümü,

ercan.taskin@dpu.edu.tr

ORCID No: 0000-0001-8499-1013

\section{Özden Sevgi AKINCI}

Doktora Öğrencisi, Kütahya Dumlupınar Üniversitesi, Lisansüstü Eğitim Enstitüsü,

Uluslararası Ticaret ve Finansman Anabilim Dall,

osevgiakinci@hotmail.com

ORCID No: 0000-0002-9250-4446

Bu makaleye atıfta bulunmak için: Taşkın, E. \& Akıncı, Ö.S. (2021). "Covid-19 Küresel Salgınının Uluslararası Ticarete Etkileri”. Alanya Akademik Bakış, 5(2), Sayfa No.749-771.

\section{ÖZET}

\section{Anahtar kelimeler:}

Uluslararası Politik

Ekonomi,

Uluslararası Ticaret,

Küresel Salgınlar,

Küresel İşbirliği,

Sürdürülebilir

Küresel Ekonomi

Makale Geliş Tarihi:

25.10.2020

Kabul Tarihi:

25.03.2021

\section{Keywords:}

\section{International}

Political Economy,

International Trade,

Global Epidemics,

Global Cooperation,

Sustainable Global

Economy
Tarihteki küresel salgınlar incelendiğinde, her salgının beraberinde yıkıcı sonuçlarla birlikte bir değişim dönüşüm firsatı da sunduğu görülmektedir. Insanlığın başlangıcından beri, küresel salgınlar ağır, kalıcı ve derin ekonomik ve toplumsal etkiler bırakmıştır. Yaşanılan tüm bu zorluk ve dönüşümlere rağmen insanlı̆̆ın sinır tanımayan direşkenliği ve uyum yeteneği olağanüstüdür, tarihteki çeşitli örnekler ve kanıtlar buna tanıklık eder. Çalışmada Covid-19 dışında incelenmiş olan diğer salgınlar da göz önünde bulundurulduğunda, uluslararası ticaret ve ekonomik sonuçlar bağlamında ortak özellikler gözlenmiştir. Önde gelen ekonomiler anlaşmazlıklarını bir ölçüde azaltabildiği takdirde küresel ekonominin ve uluslararası ticaretin en zor şartlarda dahi sürdürülebilmesine olanak tanınabilecek anlaşmalara ve çözümlere varılabilecektir. Bu çözümlerin başında her ulusun öz tarımsal üretiminin ve glda egemenliğinin güvence altına alınmasının olanakl hale getirilmesi önemli bir yer tutmaktadır.

\footnotetext{
ABSTRACT

Examination of global epidemics in history shows that, despite destructive consequences, each epidemic offers a change-transformation opportunity. Since the beginning of humanity, global epidemics have had heavy, lasting and profound economic and social impacts. Despite all these difficulties and transformations, humanity's unlimited resilience and ability to adapt is extraordinary, and various examples and evidence in history testify to this. Considering the other epidemics examined in the study, besides Covid-19, common features were observed in the context of international trade and economic results. If the leading economies can reduce their disagreements to some extent, agreements and solutions that will allow the continuation of the
} 
global economy and international trade even under the most difficult conditions will be reached. At the beginning of these solutions, it may be possible for every nation to secure its own agricultural production and food sovereignty.

\section{GİRIŞ}

Pandemiler tüm bir kıta veya tüm bir yerküre gibi coğrafyalara yayılan, hayvanlarda veya insanlarda hastalıklara ve kayıplara yol açabilen bulaşıcı, yayılmacı, salgın hastalıklardır. Salgına dönüşebilen bir hastalığa yol açan organizmalar bakteri, parazit, mantar, riketsia veya virüs olabilmektedir. Böylelikle salgının kontrol altında tutulabilmesi ve mücadelede zaman/olanak dengesinin korunabilmesi için önlemler alınması gerekmektedir. Sosyal mesafenin korunması, karantina uygulamaları veya sınırların kapatılması bu önlemlere örnek olarak verilebilir.

Büyük doğal afetler, savaşlar ve mali krizler tipik olarak kalıcı verimlilik kayıplarıyla ilişkilendirilirken, büyük durgunluklar bazen belirli sektörlerde yeni teknolojilerin benimsenmesini teşvik etmiştir. Covid-19, üretimin otomasyonunu ve dijital teknolojilerin daha geniş bir şekilde üretime dahil edilmesini hızlandırabilir. Bu verimlilik kazanımları eşit olmayan bir şekilde dağıtılabilir ve bazı sektörlerde istihdam kayıplarına neden olabilir. Covid19 salgınının da pandemiye (bu çalışmada 'küresel salgın' olarak da atıfta bulunulmuştur) dönüşmesiyle birlikte alınan önlemler küresel ekonominin her alanını olduğu gibi uluslararası ticareti de negatif yönde etkilemiştir.

İnsanlığın başlangıcından beri, yerel ve küresel salgınlar ağır, kalıcı ve derin ekonomik ve toplumsal etkiler bırakmıştır. Yaşanılan tüm bu zorluk ve dönüşümlere rağmen insanlığın sınır tanımayan direşkenliği ve uyum yeteneği olağanüstüdür, tarihteki çeşitli örnekler ve kanıtlar buna tanıklık eder. 2020'nin başlarında, küresel tedarik zincirinin merkezi sayılan Çin, ölümcül koronavirüs salgınıyla manşetlere çıktığı sıralarda, bu derece yayılacağı genel olarak beklenmemiş olsa da tüm uluslar giderek dünyayı saran bu salgına karşı hazır olabilmek için eyleme geçmiştir.

Koronavirüsün, Nisan 2020'ye gelindiğinde, salgın yayılımı yoğunlaştıkça, tüm tedarik zincirleri ve endüstriler aniden kesintiye uğramıştır. Küresel finans piyasalarında, 2007-2009 ekonomik çöküşünden bu yana görülmemiş bir biçimde hızlı inip yükselmeler gözlenmiştir. Tüm bunlar yaşanırken, tarihin sayfaları arasından geçmiş salgınlar ve neden oldukları etkileri içeren bilgilerin araştırılması ve çıkarımlarda bulunulması hem günümüzdeki koronavirüs salgını hem de gelecekte gerçekleşebilecek küresel salgınlarla mücadelede bir yol haritası oluşturabilecektir.

Savaşlar, siyasi kararlar, buluşlar, iklim, doğal afetler, salgınlar dünya ve insanlık tarihine biçim veren, değiştiren, dönüştüren ve yön veren olgulardır. Her büyük krizden sonra büyük zaferlerin yaşandığı insanlık tarihinde Covid 19 küresel salgını da günümüze izini kazıyan ve gelecek nesillerce de etkisi hissedilebilecek önemli bir olaydır. Umutlar, Covid-19 salgınının da beraberinde getirdiği tüm felaketlere rağmen insanlık için bir farkındalık, ilerleme, yararlı bir değişim\&dönüşüm, yerküre sakinlerinin ortak geleceğinin sürdürülebilirliği için yeni bir adım için olanak vermesine yöneliktir. 
14. yüzyıldaki veba'dan, 15. yüzyıldaki suçiçeği salgınına, İspanyol Gribinden, 1957 Asya gribine kadar gerçekleşmiş olan birçok salgının dünya uluslarına olan etkileri ve onların reaksiyonları oldukça değerli dersler barındırmaktadır. Tarihteki kayıtlar, büyüklük olarak ne kadar farklı olsa da geçmişteki dünya ekonomisinin salgınlar karşısındaki performansının ortaya koyduğu göstergelerle, şimdi koronavirüs salgınıyla veya sonraki salgınlarla mücadelede köklü bilgi ve kılavuzluk sağlayacaktır.

Çeşitli araştırmalar küresel salgınların farklı ekonomik etkilerine odaklanmıştır. Yapılan yazın araştırmasında doğrudan uluslararası ticarete olan etkilerine odaklanılarak yapılan çalışmalar bulunamamıştır. Bu bağlamda çalışmanın bu yöndeki bir açığın kapatılmasına yardımcı olması umulmaktadır. Bununla birlikte Küresel salgınların ekonomiye ve çeşitli alanlara etkileri ile ilgili bazı çalışmalar aşağıda irdelenmiştir.

Donaldson ve Keniston (2016), Hindistan verilerini temel alarak yaptıkları analizde İspanyol salgınının son derece yüksek ölüm oranının, hayatta kalanları ek tarım arazileriyle baş başa bıraktığını, bu boş arazilerin ise verimde azalıma neden olmadan büyük bir hızla tarımsal kullanıma sunulduklarını göstermişlerdir. Böylece kişi başına artan servetin, sonraki birkaç on yıl boyunca hem çocuk miktarına hem de çocuk kalitesine yönelik artan yatırımlara yol açtığını araştırmışlardır. En çok etkilenen bölgelerde grip salgını sonrasındaki dönemlerde çocukların daha sağlıklı ve daha eğitimli oldukları saptanmıştır.

Obrizan v.d. (2020) yine İspanyol grip salgınının İsveç ekonomisi üzerindeki uzun vadeli etkilerini inceledikleri ampirik çalışmalarında, İsveç’e özellikle odaklanmış olduklarını belirtmişlerdir. İlk olarak, salgından kaynaklı can kayıpları çok iyi belgelenmiştir, ikincisi, yüksek kaliteli verilerin varlığı, üçüncüsü, Birinci Dünya Savaşında İsveç’in tarafsızlığı böyle bir çalışmanın gerçekleştirilebilmesinde savaşla bağlantılı birçok etkiden soyutlanılmasını sağlamıştır. Ancak savaş İsveç ekonomisini de hem negatif hem de pozitif olarak etkilemiştir. Ekonominin bazı sektörleri savaştan yarar sağlamıştır. Savaşan ülkelere hammadde ihracatı önemli ölçüde artmış ve İsveçli tarım, rekabetçi ithalat eksikliği nedeniyle iyi bir performans göstermiştir ve bu da büyük bir ticaret fazlasının verilmesine neden olmuştur.

Alpago ve Oduncu (2020), Koronavirüs salgınının sosyo-ekonomik sonuçlarını inceledikleri çalışmalarında korona virüs salgınının başta sosyo-ekonomik yaşam olmak üzere eğitim, sağlık ve sosyokültürel alanlarda değişim ve dönüşümlere ne şekilde yol açacağı değerlendirilmiştir. Çalışmada bu değişim ve dönüşüm sürecinin dijitalleşme ve online işlemler yönünde ağırlık kazanacağı savunulmuştur.

James \& Sargent (2007), 1957 Asya Gribi salgınının ticari ve ekonomik etki belirtileri için söz konusu dönemin aylık verilerini incelemişlerdir. Kanada endüstriyel üretiminin aylık büyümesini ve hastalık kaynaklı aşırı devamsızlık oranındaki ters aylık değişime odaklanmışlardır. ABD ve Kanada'da o dönemde iyi tutulmuş olan bu bağlamdaki verileri işleyerek yaptıkları analizde, Kanada'nın perakende satışlarında salgın kaynaklı bir etki görülmediğini öne sürmüşlerdir. Aynı biçimde bu çalışmada ABD kişisel tasarruf oranında da küresel salgına ait herhangi bir etki tespit edilememiştir. James \& Sargent'a göre, genel olarak, 1957 küresel salgınında ortaya çıkan tablonun olası çok küçük doğrudan ekonomik etkileri olmuştur ve dolaylı etkileri olmamıştır.

Yoneyama ve Krishnamoorthy (2010), 19 ülkenin verilerini ele alarak oluşturdukları bir model üzerine inşa ettikleri ampirik çalışmalarında 1957-58 Asya gribinin yayılımında soğuk savaşın etkilerini incelemişlerdir. Böylelikle söz konusu çalışma, dönemin birçok yönüne etkide 
bulunmuş olan Soğuk Savaş’ın göz önünde bulundurulması açısından diğer çalışmalardan sıyrılmaktadır. Salgın sırasında Soğuk Savaş nedeniyle Batı ve Doğu ülkeleri arasındaki bazı kısıtlamaların salgının yayılmasını etkilemiş olduğunu ortaya koymuşlardır. Uyguladıkları deneyler ve simülasyonlar, çalışmaya dahil edilen bütün ülkelerde salgının etkisinin uluslararası ilişkilerden kayda değer ölçüde etkilendiğini göstermiştir. Bu çalışma, Soğuk Savaş'ın etkisinin daha az olması durumunda, Batılı uluslarda çok daha fazla sayıda ölüm vakası olabileceğini, Doğu uluslarında ise daha az sayıda ölüm vakası olabileceğini ve küresel etkisinin bir miktar daha artabileceğini göstermiştir.

Burada belirtilen çalışmaların tümü küresel salgınların iki dünya savaşında karşılaşılan ekonomik, sağlık ve ticari zorluklarından daha ağır olduğu bağlamında ortak görüşe sahiptir. Ticari faaliyetlerin tamamen veya oldukça düşük olmakla birlikte belli bir ölçüde durduğu, bununla birlikte ekonomik ve ticari toparlanmanın da oldukça hızlı olduğu yönündeki çıkarımlar da bu konudaki çalışmaların görüş birliğine işaret etmektedir.

Çalışmanın ilk bölümünde seçilmiş küresel salgınların süreci ve uluslararası ticarete etkileri araştırılmıştır. Bir sonraki bölümde Covid-19 salgını öncesi ve salgın Sürecinde ekonomik ve ticari genel duruma odaklanılmıştır. Bu bağlamda Covid-19 öncesi uluslararası ticaret ve küresel ekonomi ortamı incelenmiş ve salgının uluslararası ticarete olan etkileri irdelenmiştir. Son bölüm, çalışmada elde edilen bulgular 1şığında varılan anlayışları ve sonuçları içermektedir.

Günümüzde yaşanmakta olan bu küresel salgın sırasında veya sonrasında küresel ekonominin ve uluslararası ticaretin kısa vadeli acil çözümlere ihtiyaç duyuyor olması, daha sürdürülebilir uzun vadeli çözümlerin de ortaya konulmasının gerekliliğinin göz ardı edilmesine neden olmamalidır.

\section{SEÇILMIŞ KÜRESEL SALGINLARIN SÜRECİ VE ULUSLARARASI TICARETE ETKILERİ}

Büyük salgınlar, neolitik çağlardan beri geçmişin tarım dünyasına damgasını vurmuştur. Avcı ve toplayıcı olanlarına göre çok daha yoğun nüfuslu toplumların oluşumu ve evcil hayvanlarla günlük temas geçtiğimiz 10,000 yıl boyunca insanlığa eşlik etmiş olan ağır salgın hastalıkların kaynağıdır. Nüfusun yoğunluğu ve hareketliliği ile kötü beslenme sıklıkla bu salgınların belirleyici etkenleri olarak değerlendirilmiştir. Hastalıkların yayılmasında nüfus ile doğal kaynaklar arasındaki ilişki önemli bir role sahiptir, ama talih de önemli bir rol oynamaktadır (Malanima, 2012: 311).

Küresel salgınların uluslararası ticarete ve ekonomiye genel etkileri hakkında bir anlayış elde edebilmek amacıyla tarihteki dört küresel salgın kısaca incelenmiştir. İncelenen salgınlar sırasıyla, genellikle yalnızca Avrupa'da tutulmuş olan kayıtlarının günümüze ulaşmış olduğu 1347-1350 yılları arasındaki veba salgını, 15. Yüzyılın sonundan başlayarak 16. Yüzyıl boyunca gerçekleşmiş olan çiçek hastalığı salgını, 1918 yılında fark edilen İspanyol gribi salgını ve 1957 yılında ortaya çıkan Asya gribi salgınıdır. Bir sonraki sayfadaki Tablo 1'de, seçilmiş olan pandemilerin, yaşanmış diğer pandemilerle karşılaştırmalarının yapılabilmesi amacıyla, en yüksek insan kaybı ile sonuçlananlarından on beşinin gösterilmesi amaçlanmıştır.

\subsection{Veba Salgını - 1347-1350}


On dördüncü yüzyıl, büyük felaketlerle sarmalanmış, önemli sistemik değişim ve dönüşümlere maruz kalmış ve küresel insan nüfusunda belirgin bir gerilemenin yaşandığı bir yüzyıl olarak öne çıkmıştır. Yüzyılın başındaki kıtlık Avrupa kıtasında büyük bir yıkıma neden olmuştur. Bundan otuz yıl sonra 1347-1350 yılları arasında gerçekleşen Kara Ölüm (Black Death) olarak adlandırılmış olan veba salgınının Avrupa nüfusunun yaklaşık üçte birini kırmış olduğu tahmin edilmiştir (Pirenne, 2009: 216).

Avrupalılar, haçlı seferlerinden önce ender olarak doğuya seyahat ederdi. Haçlılarla birlikte, Avrupa'da nadir olan ipek ve baharat yeniden keşfedildi, böylece Asya'ya doğru yeni ticaret yollarının oluşturulması yönünde bir isteği uyandırdı. Bunun sonucunda, bireyler, krallıklar ve kıtalar arasındaki alışveriş yaygın hale geldi. Sonuç olarak, Avrupa krallıkları yeni ticaret yollarını keşfetmeye başladı ve ticaret, 13. yüzyılda önemli ölçüde genişledi, kentleşmeyi ve yoğun yaşam koşullarını arttırdı. Kalabalık nüfuslu şehirlerin artmış olduğu ve en varlıklı evlerde bile kemirgenlerin varlığının doğal karşılandığı derecede sağlığa uygun yaşamın yokluğunda, salgın, toplumun her kademesine çok hızlı yayılmıştır (Franke, 2016: 3-5).

Salgının Çin ve Orta Asya'da başlayarak kara ve deniz ticaret yollarıyla önce Asya ve Avrupa'nın kesiştiği noktada yer alan Bizans İmparatorluğu'nun büyük ve yoğun nüfuslu başkenti Constantinople şehrine ulaştığı oradan Avrupa'nın güneyinden başlayarak İskandinavya'ya kadar tüm kıtayı sararak yayıldığı konusunda görüş birliği vardır.

Tablo 1: En az 100.000 kayıpla sonuçlanan on beş büyük pandemi olayı.

\begin{tabular}{|l|c|r|r|}
\hline Pandemi adı & Başlangıç & Bitiş & \multicolumn{1}{|c|}{$\begin{array}{l}\text { Kayıp } \\
\text { Sayısı }\end{array}$} \\
\hline Black Death (Kara Veba) & 1347 & 1352 & $75,000,000$ \\
\hline Italian Plague (İtalyan Vebası) & 1623 & 1632 & 280,000 \\
\hline Great Plague of Sevilla (Büyük Sevil Vebası) & 1647 & 1652 & $2,000,000$ \\
\hline Great Plague of London (Büyük Londra Vebası) & 1665 & 1666 & 100,000 \\
\hline Great Plague of Marseille (Büyük Marsilya Vebası) & 1720 & 1722 & 100,000 \\
\hline $\begin{array}{l}\text { First Asia Europe Cholera Pandemic (İlk Asya-Avrupa } \\
\text { Kolera Pandemisi) }\end{array}$ & 1816 & 1826 & 100,000 \\
\hline $\begin{array}{l}\text { Second Asia Europe Cholera Pandemic (İkinci Asya- } \\
\text { Avrupa Kolera Pandemisi) }\end{array}$ & 1829 & 1851 & 100,000 \\
\hline Russia Cholera Pandemic (Rusya Kolera Pandemisi) & 1852 & 1860 & $1,000,000$ \\
\hline Global Flu Pandemic (Küresel grip pandemisi) & 1889 & 1890 & $1,000,000$ \\
\hline Sixth Cholera Pandemic (Altıncı Kolera Pandemisi) & 1899 & 1923 & 800,000 \\
\hline Encephalitis Lethargica Pandemic & 1915 & 1926 & $1,500,000$ \\
\hline Spanish Flu (İspanyol Gribi) & 1918 & 1920 & $100,000,000$ \\
\hline Asian Flu (Asya Gribi) & 1957 & 1958 & $2,000,000$ \\
\hline Hong Kong Flu (Hong Kong Gribi) & 1968 & 1969 & $1,000,000$ \\
\hline H1N1 Pandemic & 2009 & 2009 & 203,000 \\
\hline
\end{tabular}

Kaynak: Jordà, Ò., Singh, S. R. \& Taylor, A.M. (2020). Longer-Run Economic Consequences of

Pandemics, Federal Reserve Bank of San Francisco Working Paper 2020-09.

Moğol-Tatar ordularının 1347 yılında Kırım yarımadasının güneyinde yer alan ve o dönemde Cenevizlere ait bir ticaret liman kenti olan Kaffa (Kefe) şehrini kuşattığı sırada şehrin direncini kırmak için vebalı cesetleri mancınıklarla şehre firlatmaları nedeniyle hastalığın Ceneviz tüccarlarına bulaştığı da kayıtlara girmiştir. Böylelikle bu tüccarlar önce Kefe'den İstanbul'a sonra da İtalyan şehirlerine seyahat ederek salgının yayılmasına neden olmuşlardır. Böylece 
salgın 1848 baharında Fransa, İtalya ve Kuzey Afrika'da yayılmıştır (Özden ve Özmat, 2014: 64; Acemoğlu \& Robinson, 2014: 69).

Tarihteki en yıkıcı salgın olarak sıyrılan bu salgın, sosyoekonomik açıdan değişimleri de beraberinde getirmiştir. Önemli ekonomik etkilerinden biri yüksek fiyat dönemini başlatmasıdır. Devletler fiyatların düşürülebilmesi için ek önlemler almak durumunda kalmıştır. Ayrıca tüketici sayısının azalmış olması ile pazarın massetme yeteneğinin bir bölümünü kaybetmiş olması da salgınının bir sonucu olarak görülmektedir (Pirenne, 2009: 217).

Öte yandan tüccarlar malların ve insanların hareketine konmuş olan yasakların ticareti azaltabileceği veya tamamen sona erdireceği savıyla salgına karşı alınan önlemlere karş1 çıkmışlardır. Feodal emek temelli hizmetlerin gittikçe azaldığı, kapsayıcı bir emek piyasasının gelişmeye başladığı bir döneme girilmiştir. Doğu Avrupa'da bulunan mülk sahiplerinin topraklarını genişlettiği bu dönemde, Batı Avrupa'nın talebini karşılayabilmek için arzı arttırma yoluna gittikleri ve emek piyasasına yönelik baskılarının yoğunlaştığı kaydedilmiştir (Acemoğlu \& Robinson, 2014: 70).

Nüfus ve işgücündeki büyük düşüşler nispi faktör fiyatlarında ve sektörel ticaret koşullarında da önemli değişikliklere yol açmıştır. Veba'nın ilk ortaya çıkışını takip eden yüzyıl boyunca çoğu ülkede ve şehirde reel ücretler iki katına çıkmıştır. Toprak emeğe göre daha bol hale geldikçe, özellikle yüksek emek içeriğine sahip ürünlerle karşılaştırıldığında tarımsal ürün fiyatları düşmüştür. Tüm bu değişikliklerin; toplam fiyat seviyesi, ticaret dengesi ve para stoku üzerinde önemli etkileri olmuştur (Pamuk, 2007: 294-295).

Sonuç olarak bu dönemdeki veba salgını sonrasında, işgücü, feodal bağımlılık zincirlerini kırmış ve artık pazarlık yapabileceği bir konuma gelmiştir. Belirli iş kollarında oluşan işçi azlığ1 ve sanayi mallarına artan talep, çalışma programlarına ve saatlerine önem kazandırmıştır. Kara ölüm, köylülerin ve serflerin özgürleşmesine çok büyük etki yapmıştır. Yaşanan işgücü eksikliği nedeniyle kırsal bölgelerde dahi paraya dayalı olan ekonomiye geçiş eğiliminin hızlandığı kayıtlara geçmiştir. Ticaretin ve ticaretle ilişkili olarak taşımacılığın işleyişi ve genel kuralları oldukça kayda değer değişikliklere uğramıştır. Nüfustaki azalma belirli bir ölçüye kadar gıda maddelerine olan talebin azalmasına neden olmuş ve kiralar ile fiyatlardaki artışı beraberinde getirmiştir. Bunun sonucu olarak lüks mallardan bazılarının fiyatı artarken, bölgesel ve yerel ticaret hacmi zayıflamıştır. Salgın nedeniyle alınan önlemler sonucunda mal ve insan hareketliliğindeki kısıtlamalar Avrupalı tüccarların dünyanın diğer ülkelerine genişleyen müşteri arayışlarına yol açmıştır (Acemoğlu \& Robinson, 2014: 77-81). İnsanlar yaşamsal gereksinimleri dışındaki harcamaları kısmış ve günlük geçimleri için çalışmak zorunda kalmıştır. Bazı toprak sahipleri sözü edilen bu genel yoksulluktan yararlanmıştır (Malanima, 2012: 325).

Ücretleri artan tek kesimin işçiler veya köylüler olmadığını da belirtmek gerekir. Hastalığa çare bulmaları için başvurulan doktorların ve cerrahların ücretinin de iki katına çıkarılmış olduğu not edilmiştir. Öte yandan, noter ve mezar kazıcılarının da ücretleri artmış ve hatta bu meslek gruplarından olanlar her istenildiğinde bulunamaz olmuşlardır. Veba kaynaklı olumsuz koşullar uluslararası ticareti temeline kadar sarsmıştır. Hem deniz hem de kara ticareti durmuştur. Avrupa dişından gelen gemilerin Avrupa limanlarına yanaşmalarına izin verilmezken, denizcilerin birçoğunun vebadan ötürü yaşama veda etmiş olmaları nedeniyle kıtadan da gemi çıkışı durmuştur. Veba salgını öncesiyle karşılaştırıldığında halkın ekonomik 
koşullarında ve yaşam standartlarında önemli iyileşmeler olduğu gözlenmiştir. Tüketici sayısının azalması sebebiyle birçok ürünün fiyatı düşmüş ve halk daha iyi beslenebilmiştir. Buna karşılık tıbbi ilaç ve bitkiler, mum, tabut ve kefen malzemelerinin fiyatlarında kayda değer artışlar olmuştur (Genç, 2011, 133-140).

\section{2. Çiçek Hastalığı Salgını - 15. - 16. Yüzyıl}

Çiçek hastalığının insanlara ilk olarak 12,000 yıl önceki en erken tarımsal yerleşimler sırasında bulaştığ 1 düşünülmektedir. Genel olarak kabul edilmiş olan görüş, virüsün develerden veya evcilleştirilmiş diğer evcil hayvanlardan insanlara geçtiğini göstermektedir. Afrika, Avrupa ve Asya'da genişlemiş ve o zamanki bilinen dünya nüfusunda ölüm oranı yaklaşık olarak \%3 olmuştur. Bu oran Amerika kıtasının keşfinden sonra tamamen yeni bir görünüm almıştır.

Amerika kıtasının Avrupalılar tarafından fethedilmesi, üstün silahlarla donatılmış askeri örgütlenmeye sahip olmalarının yanı sıra Avrupalıların bağışık olduğu ama yerli halkın bu bağışıklıktan yoksun olduğu bulaşıcı hastalıkların yenidünyada yayılmasına da dayandırılabilir. İspanyol ve İngiliz kaşifler ile maceracılar bağışık oldukları başta çiçek ve kızamık olmak üzere çeşitli hastalıkları da beraberlerinde yenidünyaya taşımışlardır. $O$ dönemin Kuzey Amerika'sında toplumlar küçüktü ve birbirlerinden yalıtılmış halde yaşam sürmekteydiler ve bu da o bölgelerdeki toplumlarda bu tür bulaşıcı hastalıkların yayılımını zorlaştırmıştır. Bunun yanında Meksika ve Peru'da ise halk kitleleri gerekli taşıma kapasitelerine ulaşmaya başlamış olan oldukça büyük şehirlerde yoğunlaşmış durumdayd1. Yoğunluklarına rağmen bu şehirlerde bulaşıcı hastalıklar neredeyse yok denecek kadar azdı. Bu nedenle Avrupalıların getirdiği bulaşıcı hastalıklara karşı oldukça savunmasız durumdaydılar (Bell \& Lewis, 2005: 141).

Sözü edilen dönemde Amerika kıtasında yaşanmış olan nüfus azalımının gerçek boyutu hakkında günümüze kesin bir bilgi ulaşmamış olsa da ve çeşitli kaynakların üzerinde durduğu sayılar birbirini tutmasa da 1492'den itibaren ilk 100-150 yıl içinde yerli Amerikan nüfusunun yaklaşık olarak \%80-95 oranında azaldığı tahmin edilmektedir. Örneğin, kıtanın doğusunda yer alan ve Kolomb'un karaya ilk çıktığı Hispaniola adasındaki yerli Taino halkının 60,000 veya 8 milyonu bulan nüfusu (çeşitli kaynakların oldukça farklı bir sayılar vermektedir) sonraki 50 yıl içerisinde neredeyse tükenme noktasına gelmiştir. Kimi tarihçilere göre 3-4 milyon'dan \%95 oranında bir azalım söz konusudur, ama oranlar bağlamındaki yaklaşımlar genellikle birbirini tutmaktadır. 1519 yılında 15 milyonu bulan Meksika nüfusu, yüz yıl sonra yaklaşık olarak 1.5 milyona düşmüştür. Benzer bir azalma, çiçek hastalığının ortaya çıkmasının yerli nüfus için feci sonuçlara yol açtığı bugünkü Amerika Birleşik Devletleri’nin doğu kıyısında da meydana geldi ve hastalık, Avrupa sömürgeciliğinin acımasız süreci boyunca yayılmaya devam etti. Tarihçi ve demografi uzmanı Nobel David Cook, her şey sona erdiğinde Amerika kıtasındaki bölgelerde salgınlardan en az etkilenen bölgelerde nüfusun \%80'inin, en çok etkilenen bölgelerde nüfusun tamamının ve ortalama düzeyde etkilenen bölgelerde ise halkın \%90'ının yok olduğunu tahmin etmiştir (Nunn \& Qian, 2010: 165; (Barquet \& Domingo, 1997: 635).

İspanyolların yeni kıtada uyguladığı repartimiento sisteminin ve madenlerde zorla çalıştırmanın yerlilerin yaşam mücadeleleri üzerindeki etkisiyle ilgili çok fazla görüş öne sürülmüştür. Bununla birlikte, 1518 yılında patlak veren çiçek salgını, yaşam mücadelesini sürdürmeye çalışan ve hayatta kalan yerlilerin büyük bir çoğunluğunun yok olmasına neden olmuştur. Böylece madenlerden çok az miktarda altın elde edilebilmiştir. Ardından Afrikalı kölelerin giderek artan insan gücünün desteğiyle şeker kamış1 tarlaları başlatılmıştır. 1520'lerin 
başında, birkaç bine indirgenmiş olan yerli nüfus ise yok olmaya yüz tutmuştur (Dorel, 2006: 3).

Ekonomik sonuçları bakımından ve uluslararası ticarete etkileri bağlamında ele alındığında, Amerika kıtasının keşfi ve ardından yayılan çiçek salgınını izleyen sürecin, iç içe örülmüş zincirleme bir takım gelişmeyi öne çıkardığı görülmektedir.

Yeni Dünya, şeker ve kahve gibi çeşitli Eski Dünya ürünlerinin yetiştirilmesi için çok uygun topraklar sağlamıştır. Patates, İrlanda ve Doğu Avrupa toplumları tarafindan, Güney ve Güneydoğu Asya kültürleri tarafından biber, İtalya ve diğer Akdeniz toplumları tarafından domates ve tüm dünya uluslarınca da tütün benimsenmiştir. Bu ürünlerin üretimi, bazılarının Sanayi Devrimi'ni ve Avrupa'nın yükselişini körüklediğini iddia ettiği, Avrupa'ya dönük büyük kar getirisi akımıyla da sonuçlanmıştır. Bu değişimin bazı olumsuz etkileri de olmuştur. Yerli Amerikan nüfusu Eski Dünya hastalıkları tarafından neredeyse yok edilmiştir. Bu nüfus azalımı ile birlikte şeker kamışı ve kahve gibi değerli Eski Dünya mahsullerinin Yeni Dünyadaki üretimi, transatlantik köle ticaretine yol açan emek talebini körüklemiştir. Bu emek talebi ise, on iki milyondan fazla kölenin Afrika'dan Amerika'ya zorla taşınmasını beraberinde getirmiş ve Afrika kıtası için yıkıcı politik, sosyal ve ekonomik sonuçlar doğurmuştur. Artan arz nedeniyle, birçok ürünün fiyatı önemli ölçüde düşmüş, birçoğunun fiyatı tarihte ilk kez genel nüfusa uygun hale gelmiştir (Nunn \& Qian, 2010: 183-184).

Genel olarak çiçek hastalığı salgınlarına bakıldığında, çiçek hastalığının batı medeniyetinin gelişimini olumlu veya olumsuz yönde büyük ölçüde etkilediği sonucuna varılır. Roma İmparatorluğu'nun M.S. 180'li yıllardaki ilk gerileme dönemi yaklaşık üç buçuk - yedi milyon insanın yaşamına son veren çok büyük ölçekli bir veba salgınına (Antoninus) denk gelmiştir. Akademisyenler yakın bir zamana kadar Antoninus vebasının çiçek veya kızamık hastalığ olduğunu öne sürmüş olsalar da son bilimsel veriler bu olasılığı ortadan kaldırmıştır (Furuse v.d., 2010: 55). Arap genişlemesi, Haçlı Seferleri ve Batı Hint Adaları'nın keşfi, hastalığın yayılmasına katkıda bulunmuştur. Yeni Dünya'da bilinmeyen çiçek hastalığı ilk olarak İspanyol ve Portekizli fatihler tarafından tanıtılmıştır. Yerel nüfusu yok etmiş ve Aztekler ile İnkaların imparatorluklarının yıkılışında etkili olmuştur. Çiçek hastalığının yıkıcı etkisi, biyolojik savaşın ilk örneklerini yansıtır. Kuzey Amerika'daki İngiliz kuvvetlerinin başkomutanı Sir Jeffrey Amherst, 1763 'te Albay Henry Bouquet'e yazdığ püstüllerinin kabuklarının, salgından henüz etkilenmemiş Amerikan yerlisi kabilelerine dağıtılacak battaniyelerin içerisine öğütülmesini önermiştir. Köle ticareti, Amerika'da hastalıkların ortaya çıkmasına da katkıda bulunmuştur, çünkü birçok köle, çiçek hastalığının endemik olduğu Afrika bölgelerinden gelmiştir (Barquet \& Domingo, 1997: 635-636).

\section{3. İspanyol Gribi (H1N1) - 1918}

İspanyol gribi olarak adlandırılmış olan 1918 grip salgını, 20. yüzyılın büyük bir bölümünde unutulmuş bir felaket olmuştur. 19 ulusun savaşta olduğu, karmaşa, baskı, gerilim ve yokluğun gribin bulaşmasını doğrudan desteklediği bir zamana denk gelmiştir. Birkaç ay içinde neden olduğu 50 milyondan fazla ölümün Birinci Dünya Savaşı'ndan kaynaklanan ölümlerden üç kat daha fazla olduğu düşünüldüğünde, bu salgının halen araştırma konusu olması önem taşımaktadır. Öte yandan başlangıçta araştırmacıların ilgisini çekmeyen grip salgını sonraki dönemlerde tekrarlanan salgınların ardından araştırmacıların yoğun ilgisiyle karşılaşmış ve böylece yazında oldukça kayda değer oranda bir yer edinmiştir. 
Günümüzde, salgına verilen isim ile ilgili bir fikir birliği vardır. 1918 baharının sonlarında, İspanyol haber servisi Agencia Fabra, Londra'daki Reuters haber servisi merkezine "Madrid'de salgın özelliklerini taşıyan garip bir hastalık türü ortaya çıktı. Salgın hafif bir doğaya sahiptir; henüz bir kayıp bildirilmedi” içeriği ile bir telgraf göndermiştir. Başlangıcından beri, salgın, muhtemelen salgının kökeni hakkındaki haberleri çevreleyen yanlış bilgiler nedeniyle İspanyol gribi olarak adlandırılmıştır. Genellikle Birinci Dünya Savaşı'nda İspanya'nın tarafsız bir ülke olması nedeniyle, o dönem İspanyasındaki basın özgürlüğünün müttefik ülkeler ve Almanya'dakinden daha fazla olduğu kabul edilir. ABD ve Avrupa basını, muhtemelen siyasi nedenlerden ötürü, devam eden grip salgınına atfedilebilen askeri ve sivil nüfusu arasındaki çok sayıda ölü ve yaralı hakkında zamanında ve doğru haber vermemiş veya bildirmemiştir. Yaklaşık 90 yıl sonra, dünya çapındaki virologlar ve epidemiyologlar grip virüsünün İspanya'dan kaynaklanmadığını kabul etseler de isim kalıcı olmuştur. Böylece 1918-1920 grip salgını her zaman İspanyol gribi olarak bilinecektir (Trilla v.d., 2008: 668; PBS, 2020).

1918 grip salgınını benzersiz kılan, ölüm oranlarının en yüksek olduğu yaş grubunun 18-40 yaşları arasındaki nüfus olduğu ve bu yaş grubundaki erkeklerin ölüm oranının da kadınlardan daha fazla olduğu idi. Genel olarak, ölüm grip virüsünün kendisinden değil, vücudun virüse karşı immünolojik reaksiyonundan kaynaklanmıştır. En güçlü bağışıklık sistemine sahip bireylerin ölümü, daha zayıf bağışıklık sistemine sahip bireylerden daha fazla olmuştur (Garrett, 2007: 8).

Genel hastalık ve ölüm oranı açısından, İspanyol gribi salgını kayıtlı tarihin en büyük halk sağlığı felaketleri arasındadır. Daha önce birbirleriyle sinırlı temasta olabilecek popülasyonların Birinci Dünya Savaşı nedeniyle bir araya getirildiği bir dönemde ortaya çıkan, oldukça patojenik, bulaşıcı bir grip türünün sonucuydu. Önceki pandemiler çoğunlukla ticaret yolları ve iletişim hatları boyunca dolaşımdayken, 1918 salgınının yayılması, içinde geliştiği askeri bağlam tarafindan hızlandırılmıştır. Bu arada, Avrupa'daki hendek savaşı hastalığın bulaşmasını kolaylaştırmak için ideal koşullar (zayıf sanitasyon, aşırı kalabalık ve sınırlı sağlık hizmetleri) sağlamıştır (Saunders-Hastings, P. R., \& Krewski, 2016: 5).

Savaştaki askerler arasında 1918 salgınının neden olduğu büyük yaşam kaybının ve böylece salgının savaşın seyrini etkilediğinin farkına varılması ilginçtir. Binlerce hasta askerin cephe önlerinden cephe gerisine transferi ve hastaneye kaldırılması, azalan ordular dışında büyük bir lojistik sorun yaratmıştır. En önemli savaş tarihçileri salgına birkaç cümle ile atıfta bulunmuşlardır. Yalnızca onlar değil, bir bütün olarak dünya sakinleri, uzun yıllar boyunca grip salgınının savaştan daha ağır sonuçlarının olabileceğini unutmuş gibiydi (Dávila, 2018: 18).

Bunun nedenleri şöyle sıralanabilir: ilk olarak, salgın Birinci Dünya Savaşı ile aynı zamanda meydana geldi. Yaşam koşulları ve son derece hareketli birimlerle yakın temasları nedeniyle grip salgını özellikle askerlere sert vurdu. Örneğin, ABD’deki günlük haberlerinin çoğu denizaşırı savaş olaylarına ve Amerikan birliklerinin mevcut durumuna odaklanmıştı. Böylece, salgın ve Birinci Dünya Savaşı iki ayrı olaydan çok neredeyse tek bir olay olarak görülmüştür. İkincisi, çocuk felci, çiçek hastalığı ve frengi gibi günün hastalıkları tedavi edilemez olarak görülüyordu ve toplumun kalıcı bir parçasıydı. Onların aksine, grip, topluluklara çabucak bulaştı, nüfustaki bireyleri öldürdü ve sahneyi hızlıca terk etti. Son olarak, çocuk felci ve çiçek hastalığından farklı olarak, grip, dönemin ünlü insanlarının ölümüne neden olmadı, dolayısıyla siyasi olarak güçlü, zengin ve ünlü figürlerin virüse karşı bağışık olmadıklarına dair bir kamuoyu algısı da oluşmamıştır (Garrett, 2007: 9). Bununla birlikte Grip salgını yalnızca ABD'de 675,000 insanın ölümüne neden olmuştur, bu sayı ABD'nin iki dünya savaşında, 
Kore'de ve Vietnam'daki kayıplarının toplamından çok daha fazladır (Brainerd \& Siegler, 2003: 3).

Uluslararası ticaret ve ekonomik sonuçları bakımından incelendiğinde, göstergelerin çoğu, 1918 grip salgınının ekonomik etkilerinin kısa vadeli olduğuna işaret etmektedir. Birçok işletme, özellikle de hizmet ve eğlence endüstrilerindekiler, çift haneli gelir kaybına uğramıştır. Sağlık hizmetleri ürünlerinde uzmanlaşmış diğer işletmelerin gelirlerinde artış yaşanmıştır. Bazı akademik araştırmalar, 1918 grip salgınının işçiler için daha yüksek ücretlerle (en azından geçici olarak) sonuçlanan bir işgücü eksikliğine neden olduğunu öne sürmüştür, ancak bu yararın muazzam yaşam kaybından ve genel ekonomik faaliyetten daha ağır bastığına dair makul bir tartışma yapılamamıştır (Garrett, 2007: 21).

Genel olarak ele alındığında, savaş sırasında ortaya çıkmış olan grip salgınının uluslararası ticaret ve ekonomi üzerindeki etkilerini birbirlerinden ayırmanın zor olduğu görülmektedir. ABD şehirlerinde, özellikle Pennsylvania, Maryland ve New Jersey gibi salgında daha yüksek kayıp oranı olan eyaletlerde işçi ücretlerinin arttı̆̆ tespit edilmiştir. Birleşik Krallık'taki veriler de işçi ücretlerinin 1918-1919 arasında \%34.2 arttı̆̆ını, ülkedeki reel GSYİH'nin ise \%6 düştüğünü ortaya koymuştur. Birinci Dünya Savaşı'na dahil olmayan bir ülke olan İsveç’te, pandemi hisse senetleri kazançlarını etkilemiştir. Ancak aynı dönemde altının fiyatı \%6.1 artmıştır (Dávila, 2018: 35).

Birinci Dünya Savaşı sırasında İsveç deneyimi genellikle iki yarıdan biri olarak tanımlanır. İlk iki yıl, artan ticaret ve GSYİH ile endüstriyel ve finansal büyüme ile karakterize edilmiştir. 1917'de ticaret kapandığında işler hızla tersine dönmüş, İsveç durgunluğa girmiş ve ardından ülke genelinde keskin fiyat artışları, gıda kıtlığı, rasyon ve gıda isyanları ve protestolar izlemiştir. Durgunluğun büyüklüğü, etkileri ve yol açtığı savaş sonrası kriz göz önüne alındığında, olumsuz ekonomik etkiler nüfusun büyük ve önemli bir kısmı tarafından hissedilse de savaşan ülkelerde yaşananlarla aynı ölçekte olmadıklarını akılda tutmak önemlidir. İsveç'in ekonomik performansı hala savaş halindeki tüm Avrupalı ülkelerinkinden fazlaydı ve eğer insan maliyeti eklenecek olursa, bu fark daha da büyük olur. Sonuç olarak, Birinci Dünya Savaşı'nın tarafsız ülkeler için zararlı sonuçları bile vardı, ancak tarafsızlık bu yankıların bir kısmını hafifletmiştir (Häggqvist, 2019: 5-6).

İspanyol Gribinin uzun vadeli etkileri hakkında da çalışmalar yapılmıştır. Bu çalışmalar arasından Vollmer ve Wójcik'in çalışması oldukça kapsamlı ve kayda değer olarak görülmektedir. İspanyol Gribinin uzun vadeli eğitimsel ve ekonomik etkilerini araştırdıkları çalışmalarında, IPUMS International tarafından sağlanan 117 nüfus sayım veri setini sistematik olarak analiz etmişlerdir. Analizlerinde 1918 gribinin salgın sırasında doğmak üzere olan bireyler (in-utero) bağlamında insan sermayesinde azalmaya neden olduğunu, fakat salgının, salgından yıllar sonra istihdam gibi ekonomik faaliyetlere tutarlı bir etkisinin bulunamadığını ortaya koymuşlardır. Böylece elde ettikleri bulgular 1şı̆̆ında, İspanyol Gribinin uzun vadeli ekonomik etkileri hakkındaki mevcut kanıtların büyük bir olasılıkla yayın yanlılığından kaynaklandığı sonucuna ulaşmışlardır (Vollmer \& Wójcik, 2017).

Brainerd ve Siegler ampirik çalışmalarının sonucunda yapmış oldukları analizlerinde bu grip salgınını, Birinci Dünya Savaşından sonra yaşanan durgunluklara katkıda bulunan bir faktör olarak görmüşlerdir. Grip nedeniyle can kaybının yüksek olduğu ABD eyaletlerinde 1919 ve 1921 arasında daha yüksek iş başarısızlıkları gözlenmiştir ve sonuç olarak mevcut akımda olabileceğinden daha fazla etkilenmişlerdir. Bu eyaletlerde 1919-1921 ve 1930 arasındaki hızlı 
büyüme, standart neoklasik büyüme modeli ve bazı endojen büyüme modellerinin tahminleriyle tutarlı olsa da en azından bir kısmı büyük bir olasılıkla mevcut akım değişikliğinden değil, salgının yarattığı olumsuz şoktan ana akıma dönüşü yansıtmaktadır. Bununla birlikte bu salgın, önemli makroekonomik etkileri olan büyük bir şok olarak kabul edilmiştir (Brainerd \& Siegler, 2003: 27).

Donaldson ve Keniston (2016), Hindistan verilerini temel alarak yaptıkları analizde salgının son derece yüksek ölüm oranının, hayatta kalanları ek tarım arazileriyle baş başa bıraktığını, bu boş arazilerin ise verimde azalıma neden olmadan büyük bir hızla tarımsal kullanıma sunulduklarını göstermişlerdir. Böylece kişi başına artan servetin, sonraki birkaç on yıl boyunca hem çocuk miktarına hem de çocuk kalitesine yönelik artan yatırımlara yol açtığını araştırmışlardır. En çok etkilenen bölgelerde grip salgını sonrasındaki dönemlerde çocukların daha sağlıklı ve daha eğitimli oldukları saptanmıştır (Donaldson \& Keniston, 2016: 21).

Obrizan v.d. (2020) grip salgınının İsveç ekonomisi üzerindeki uzun vadeli etkilerini inceledikleri ampirik çalışmalarında, İsveç'e özellikle odaklanmış olduklarını belirtmişlerdir. İlk olarak, salgından kaynaklı can kayıpları çok iyi belgelenmiştir, ikincisi, yüksek kaliteli verilerin varlığı, üçüncüsü, Birinci Dünya Savaşında İsveç’in tarafsızlığı böyle bir çalışmanın gerçekleştirilebilmesinde savaşla bağlantılı birçok etkiden soyutlanılmasını sağlamıştır. Ancak savaş İsveç ekonomisini de etkilemiştir. İngiltere deniz ablukası ve Almanların denizdeki saldırganlıkları İsveç'in ithalat ticaretine zarar vermiş ve fiyat kontrolleri ile karne sisteminin getirilmesine neden olmuştur. Aynı zamanda ekonominin bazı sektörleri savaştan yarar sağlamıştır. Savaşan ülkelere hammadde ihracatı önemli ölçüde artmış ve İsveçli tarım, rekabetçi ithalat eksikliği nedeniyle iyi bir performans göstermiştir ve bu da büyük bir ticaret fazlasının verilmesine neden olmuştur. Tersine, savaşın sona ermesinden sonra aynı sektörlerde bir gerileme yaşanmıştır. Genel anlamda, İsveç 20. yüzyılın başında sanayileşen bir ülkeydi ve nüfusun yaklaşık \%29'u imalat sektöründe çalışıyordu, bu rakam 1930'a kadar \%36'ya yükselmişti. 1917'de İsveç'te kişi başına düşen GSYİH 3.022 Geary-Kamis doları, ABD $(5,248)$ ve İngiltere (5,421) seviyelerinin oldukça altındaydı (Obrizan v.d., 2020: 7-8).

Obrizan v.d. (2020) salgının, 10 yıllık orta vadede hayatta kalanların refahı üzerinde orta derecede olumlu bir etkisi olduğu sonucuna ulaşmışlardır. Aynı dönemde, toplam değişkenler nüfus düşüşüne (işgücü hariç) esnek olmayan bir şekilde yanıt vermiştir. Son olarak, salgının ekonomi üzerinde uzun süreli etkileri ve üretim kaybı açısından büyük bir maliyeti olduğu bulgusuna ulaşmışlardır (Obrizan v.d., 2020: 21).

Çalışmada incelenmiş olan diğer salgınlar göz önünde bulundurulduğunda, İspanyol Gribinin sonuçlarında da uluslararası ticaret ve ekonomik sonuçlar bağlamında ortak özellikler gözlenmiştir. $\mathrm{Bu}$ ortak özelliklerin bazıları; nüfuz azalımı temelli işgücü kaybından kaynaklanan geçici bir ücret artışı, ekilebilir tarım arazilerinin belirli bir süre boşta kalması, uluslararası ticaretin salgını ilgilendiren alanlarda canlanıp ilgilendirmeyen alanlarda gerileyişi (burada farklı olarak Birinci Dünya Savaşının etkileriyle örülü biçimde) olarak özetlenebilir.

\subsection{Asya Gribi - 1957-58}

1957-58 Asya gribi salgınının kaynağı A(H2N2) alt tipidir. İlk olarak Çin'de ortaya çıkan virüs birkaç ay içerisinde Çin'in komşularına yayılmıştır. Haziran ayında Güneydoğu Asya ve Avustralya'ya ulaşmış, Haziran-Eylül arasında da Güney Amerika'ya ve Avrupa'ya varmıştır. ABD'ye yaz ortasında ulaşan virüs ilk olarak az sayıda insana bulaşmış olmasına rağmen, birkaç ay içinde yayılımı artmıştır. İngiltere'nin 3,550 kayıp bildirdiği (Salgın sona erdiğinde 
İngiltere'deki kayıp 14,000 olmuştur.)1957 Aralık ayından itibaren her kıtada bulaş görülmüştür. Böylelikle virüsün küresel çaptaki yayılımı on ay sürmüştür. 1958 Mart'ına kadar ABD'de 69,800 kayıp gerçekleşmiştir. 1957-58 Asya gribi salgınının dünya genelinde yaklaşık olarak 820 milyon enfekte ve 2 milyon kayıpla sonlandığ tahmin edilmektedir (Rogers, 2020; Yoneyama \& Krishnamoorthy, 2010: 1; Oxford v.d., 2001: 155).

Ayrıca, çok daha düşük hastalık oranına sahip ikinci bir dalga, ilk dalga tam olarak etkisini tamamlamadan önce Aralık ayında başlamıştır. İkinci dalga Şubat 1958'de sona ermiştir. 1918 'de olduğu gibi, etkinin çoğu ilk dalgada meydana gelmiş ve bu dalga içinde de etkinin çoğu tek bir ayda meydana gelmiştir (James \& Sargent, 2007: 10).

Asya gribi, küresel gözetim sistemleri ve onu incelemek için laboratuar yetenekleri olan bir ortamda ortaya çıkan ilk pandemi olarak kayıtlara geçmiştir. 1957'de dünya çapında bir laboratuar ağı Londra merkezli Influenza Araştırma Merkezine bağlanmıştır ve Melbourne'dan Washington'a araştırmacılar salgının ortaya çıkmasından kısa bir süre sonra bu tür üzerinde çalışabilmişlerdir (Saunders-Hastings, P. R., \& Krewski, 2016: 8).

Yoneyama ve Krishnamoorthy (2010), 19 ülkenin verilerini ele alarak oluşturdukları bir model üzerine inşa ettikleri ampirik çalışmalarında 1957-58 Asya gribinin yayılımında soğuk savaşın etkilerini incelemişlerdir. Böylelikle söz konusu çalışma, dönemin birçok yönüne etkide bulunmuş olan Soğuk Savaş’ın göz önünde bulundurulması açısından diğer çalışmalardan siyrilmaktadir.

Salgın sırasında Soğuk Savaş nedeniyle Batı ve Doğu ülkeleri arasındaki bazı kısıtlamaların salgının yayılmasını etkilemiş olduğunu ortaya koymuşlardır. Uyguladıkları deneyler ve simülasyonlar, çalışmaya dahil edilen bütün ülkelerde salgının etkisinin uluslararası ilişkilerden kayda değer ölçüde etkilendiğini göstermiştir. Bu çalışma, Soğuk Savaş'ın etkisinin daha az olması durumunda, Batılı uluslarda çok daha fazla sayıda ölüm vakası olabileceğini, Doğu uluslarında ise daha az sayıda ölüm vakası olabileceğini ve küresel etkisinin bir miktar daha artabileceğini göstermiştir (Yoneyama \& Krishnamoorthy, 2010: 1). Bu nedenle Soğuk Savaşın, bazı ülkeler için, özellikle Batı ülkeleri için salgının baskılanması bağlamında etkin olduğu ve uluslararası ilişkinin, salgının yayılımında önemli bir faktör olarak rol aldığı görülmüştür.

Öte yandan, İspanyol Gribinde olduğu gibi önde gelen uluslararası kuruluşların ve ulusların yayınları veya raporlarında, 1957-58 Asya gribinin ekonomik etkileri üzerinde de çok az durulmuştur. Örneğin salgına denk gelen döneme damgasını vuran küresel resesyon dalgası bu salgınla pek ilişkilendirilmemiştir. Uluslararası Para Fonunun (IMF), o zamanki kısa adıyla GATT olan Uluslararası Ticaret Örgütünün (WTO) veya Dünya Bankası'nın o dönemdeki yayınlarında veya 1959 ve takip eden yıllara ait yıllık raporlarında bu ilişkilendirmeye rastlanılmamıştır. Ağustos 1958'deki FED incelemesi de bu salgına değinmemiştir.

Kanada ve ABD'de, 1957 yazının sonlarında başlayan ve 1958 baharında sona eren bir sermaye yatırımı resesyonu yaşanmıştır. Bu durgunluktan önce parasal daralma ve hisse senedi piyasası zafiyeti dönemi olmuş ve öncü göstergelerle doğru bir şekilde tahmin edilmiştir. Durgunluk, keskin sermaye malları stok döngüsü ile karakterize edilmiştir.

ABD'de, 1957'nin son çeyreğinde büyüme oranı (yıllık bazda) \% -4 ve 1958'in ilk çeyreğinde \% -10 olmak üzere, İkinci Dünya Savaşı sonrası tarihte en büyük düşüş olarak kaydedilmiştir. 1958'in üçüncü ve dördüncü çeyreğinde, büyüme oranı yaklaşık \%10'a yükselmiştir ve yıl 
boyunca GSYİH \%1'den daha az düşmüştür, bu durum kötü bir resesyonla sonuçlanmıştır. Bununla birlikte, birçok kaynak pandemiyi durgunluğun nedenlerinden biri olarak listelememektedir. Söz konusu resesyon dünya çapındaydı, bu da salgının bu küresel resesyon üzerinde etkisinin olmuş olabileceği düşüncesini güçlendirmektedir (Tabarrok, 2020: 1).

James \& Sargent (2007), 1957 Asya Gribi salgınının ticari ve ekonomik etki belirtileri için söz konusu dönemin aylık verilerini incelemişlerdir. Kanada endüstriyel üretiminin aylık büyümesini ve hastalık kaynaklı aşırı devamsızlık oranındaki ters aylık değişime odaklanmışlardır. ABD ve Kanada'da o dönemde iyi tutulmuş olan bu bağlamdaki verileri işleyerek yaptıkları analizde, Kanada'nın perakende satışlarında salgın kaynaklı bir etki görülmediğini öne sürmüşlerdir. Aynı biçimde bu çalışmada ABD kişisel tasarruf oranında da küresel salgına ait herhangi bir etki tespit edilememiştir. James \& Sargent'a göre, genel olarak, 1957 küresel salgınında ortaya çıkan tablonun olası çok küçük doğrudan ekonomik etkileri olmuştur ve dolaylı etkileri olmamıştır. James \& Sargent (2007) çalışmalarında büyüme oranlarındaki düşüş, işsizliğin yükselmesi ve uluslararası ticaretteki geçici yavaşlama dikkate alınmamıştır. Bu açıdan bakıldığında daha çok yönlü bir çalışma olması durumunda sonuçların değişebileceği yönünde bir olasılığı düşündürmektedir.

Örneğin Stepek (2020), Asya gribinin 1957'deki resesyona veya borsa çöküşlerine hiçbir etkisi olmadığı fikrinin çok zorlanmış bir sonuç görünümü verdiğini savunmuştur. Bu amaçla incelemiş olduğu bazı araştırmalarda grip salgınının resesyona veya borsa çöküşüne neden olmasından çok rastlantısal olduğu ima edilmiştir. Ama söz konusu araştırmalarda resesyona veya borsa çöküşüne nelerin neden olduğu tam olarak ortaya konulamamıştır. Örneğin, özellikle otomobil satışları önemli ölçüde düşmüştür. 1955'te ABD'de sekiz milyon araç satılmıştır (1960'ların başına kadar görülmeyecek bir zirve). 1958'de sadece 4.3 milyon satılmıştır. Tüketici harcamaları ise 1958 'in ilk çeyreğinde negatif bir hal almıştır ve bu da çok nadir görülen bir durumdu. Ekonomik cephede, işsizlik Ăgustos 1957'de \%4.1'den 1958 yazında \%7.5'e yükselmiş ve 1959 'un ortalarına doğru \%5'e düşmüştür. Bu kayda değer gibi gelmeyebilir ve oldukça kısa sürmüştür. Ama yine de gerilemenin yarattığı çaresizlik dikkat çekiciydi. Stepek, bu sonuçların Asya Gribine bağlanması gerektiğini savunmuştur (Stepek, 2020: 1-2).

Saunders-Hastings ve Krewski (2016)' ye göre, okul ve işyerlerinde salgından ötürü raporlu hastalar bağlamındaki devamsızlık nedeniyle bazı toplumsal aksaklıklar görülmüştür, ancak bu çoğunlukla çocuklar, okul öğretmenleri ve sağlık çalışanları arasında yoğunlaşmıştır. Pandemi tepe noktasında, ABD'de iş devamsızlığ $\%$ 3-8 arasında olmuştur. Ekonomik etki küçük olarak kaydedilmiş, pandemi en zirve noktası sırasında Kanada'da sanayi üretimini yaklaşık \%1.2 oranında düşürmüştür ve ABD'deki GSYİH'yi yaklaşık \%1 oranında azaltmıştır. Pandeminin geçmesinin hemen ardından ekonomik iyileşme neredeyse anında gerçekleşmiştir. (SaundersHastings, P. R., \& Krewski, 2016: 7).

Richards (2020), Asya Gribinin en yoğun olduğu dönemlerde, hem ABD'de hem de Küresel çapta bir resesyonun varlığının göze çarptığını vurgulamıştır. Genel olarak, 1958 Resesyonu (Eisenhower Resesyonu olarak da bilinir) yeterince dikkat çekmemiştir, çünkü nispeten büyüklük olarak keskinken (1930'lardan beri en kötüsü) süresi de oldukça kısaydı. Eisenhower Resesyonu Ağustos 1957'de başlamış ve Nisan 1958'de sona ermiştir. Durgunluğun nedenleri hakkında çok az yazılı rapor bulunmuştur. Daha önceki oran artışlarına bazı referanslar olsa da, neden-sonuç bağlantısı yeterli oranda kurulmamış ve geri planda kalmıştır. Çoğunlukla, 1950'lerin ortalarındaki ekonomi, yıllık bazda \%2-3 oranında bir büyüme hızında 
seyretmekteydi. 1957'nin ikinci yarısında ve 1958'in başlarında ani bir yavaşlama meydana gelmiş ve ardından güçlü bir toparlanma olmuştur. Richards, dönemin diğer tüm etkileri de incelendiğinde, zamanlama ve davranışsal etkilere bağlı olarak, resesyonun en büyük suçlusunun Asya Gribi olması gerektiğini ortaya koymuştur. Ayrıca Asya gribi ve Covid-19'un yapısal benzerlikleri nedeniyle de Covid-19'un da resesyonla sonuçlanabileceği tahmininde bulunmuştur (Richards, 2020: 5-6).

Sonuç olarak 1957 Asya Gribinin küresel çapta bir resesyona neden olduğu belirtilebilir. Geçici bir süre lüks tüketim mallarına olan ilginin de azaldığı görülmektedir. Geçici bir işsizlik görülmüş ve büyüme rakamlarında ani bir yavaşlamanın ardından hızlı bir toparlanma görülmüştür. Uluslararası kurumların ve önde gelen ekonomilerin değerlendirme kurumlarının pandeminin uluslararası ticareti ne derece etkilediğine dair yeterli bilgi bulunamadığından uluslararası ticareti nasıl etkilediği ile ilgili bir sonuç elde edilememiştir. Yalnızca otomobil satışlarının kısa bir süre için yarı yarıya düşmesiyle ilgili elde edilen veriden ve tüketici harcamalarının etkilenmiş olması nedeniyle uluslararası ticarette geçici bir durgunluk yaşanmış olabileceğine yönelik bir çıkarımda bulunulmuştur.

\section{COVID-19 SALGINI ÖNCESİ VE SALGIN SÜRECİ}

Covid-19 virüsü, 7 Ocak 2020'de insana geçişi belirlenmiş olarak tanımlanan, korona virüs ailesinden SARS- CoV ve MERS-CoV gibi zarflı bir RNA virüsü olup yüksek solunum yetmezliğine neden olmaktadır. Bu nedenden ötürü, salgının yaygınlaşmasıyla birlikte solunum cihazlarının solunum yetmezliği çekenlere oranla yeterli olmasının önem taşıdığı bir salgın olarak öne çıkmıştır. İlk olarak 31 Aralık 2019 tarihinde Çin'in Hubei eyaletindeki 11 milyon nüfusa sahip Wuhan şehrinde saptanan bir olguda daha önce hiç görülmemiş olan yeni tip bir Koronavirüs enfeksiyonunun hayvanlardan insanlara bulaştığı düşünülmüştür (TÜBA, 2020: 27).

Şimdilerde, hastalık insandan insana hızla bulaşmaya devam etmektedir. Çin'den başlayarak tüm diğer kıtalara yayılmış, Ağustos 2020 itibariyle, onaylanmış hasta sayısı 25 milyona ve kayıp sayısı ise 750 binlere dayanmıştır. Covid-19 salgını, halen pandemi seviyesindeki seyrini sürdürmekte ve bazı ülkelerde ikinci dalgalara rastlanmaktadır. Karantina uygulamaları nedeniyle Uluslararası Ticaretteki keskin düşüş ve Küresel Ekonominin geldiği nokta nedeniyle günümüzde Covid-19 salgınına bağlı olarak küresel bir resesyon yaşanıldığı genel olarak kabul edilmektedir.

Bu bölümde Covid-19 salgınının hemen öncesindeki genel ekonomik durum kısaca ele alınmış, Covid-19 salgını sırasındaki genel çerçeve çizilmiş ve Pandemi nedeniyle alınan önlemlere değinilmiştir.

\subsection{Covid-19 Öncesi Uluslararası Ticaret ve Küresel Ekonomi Ortamı}

2019'un son çeyreği kapanırken, ticaret savaşları, petrol fiyatlarındaki düşüş ve bu düşüşün ne kadar süreceği en önemli gündem maddeleriydi. Bunlara ek olarak IMF, 2019 yılının sonuna doğru Ekim ayında yayınladığı Küresel Finansal İstikrar Raporunda (Global Financial Stability Report) Küresel Finansal Sisteminin ana zayıf noktalarını şöyle sıralamıştı: Artan kurumsal borç yükleri, kurumsal yatırımcılar tarafından daha riskli ve likit olmayan varlıkların artması, gelişmekte olan ve yükselen piyasa ekonomisi olma yolunda sınırda olan (frontier market economies) piyasa ekonomilerinin dış borçlanmaya daha fazla güvenmesi (IMF, 2019: ix). 2020'de ise Covid 19 pandemisi ile birlikte bu genel tablo yeniden şekillenmiştir. 


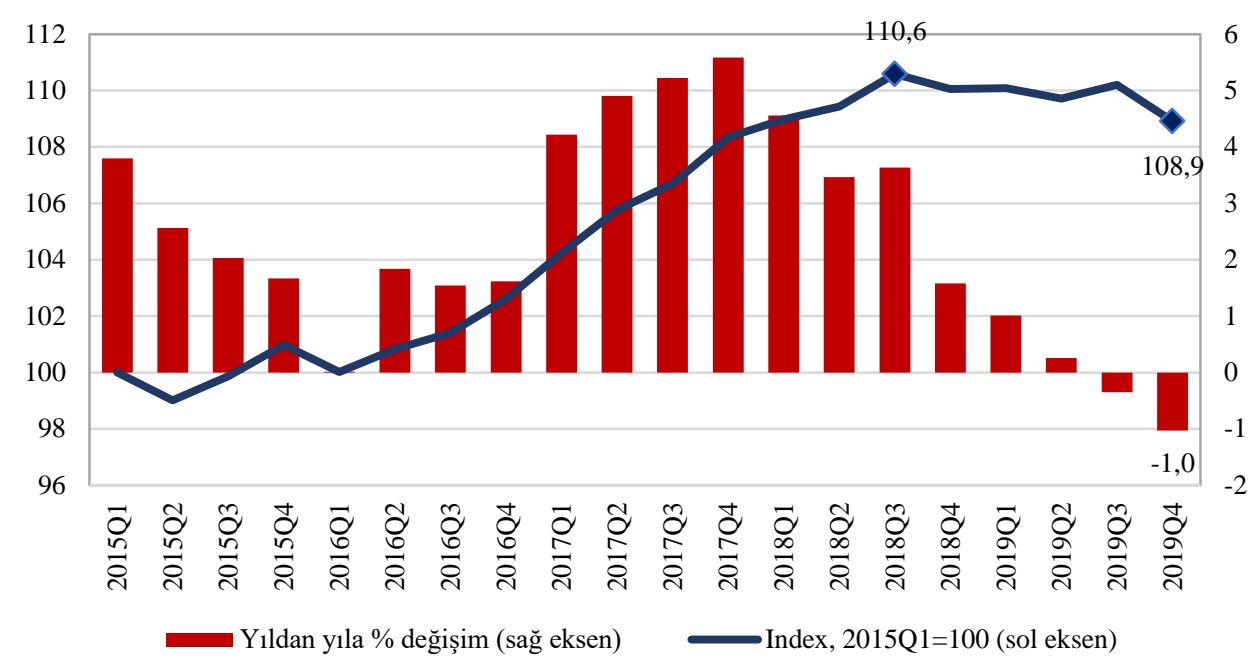

Şekil 1. Dünya emtia ticaret hacmi, 2015 Q1 - 2019 Q4 (Hacim endeksi 2015=100 ve yıllık\% değişim)

Kaynak: WTO. (2020). World Trade Statistical Review 2020.

Şekil 1'de de görüldüğü gibi, mevsimsellikten arındırılmış emtia ticaret hacmi 2019'un dördüncü çeyreğinde 2018'in aynı dönemine göre yüzde 1.0, üçüncü çeyreğe göre ise yüzde 1.2 azalmıştır. $\mathrm{Bu}$, yıllık bazda yüzde 4.6'lık bir düşüşe eşdeğerdir. ABD ve Çin arasındaki uzun süredir devam eden ticaret anlaşmazlığı, tarifelerin artırılmasına yol açmış ve 2019 yılında ticaret politikası belirsizliğine katkıda bulunmuştur. Ekonomik belirsizliğe katkıda bulunan diğer faktörler arasında 2018-19'da Amerika Birleşik Devletleri'nde hükümetin kapatılması ve federal hizmetlerin durdurulması, Birleşik Krallık'ın Avrupa Birliği'nden ayrılması ve büyük ekonomilerde para politikasındaki değişiklikler yer almaktaydı.

\subsection{Covid-19 Salgını Sırasında Genel Çerçeve}

Covid-19 salgını, yakın geçmişte yaşanmış en derin ekonomik krizine yol açmıştır. Üretim düşüşe geçmişken iş kayıpları da artmıştır. Ticaret ise, arz ve talep şokları nedeniyle ciddi şekilde kesintiye uğramıştır.

1870 'ten beri dünya ekonomisi 14 küresel durgunluk yaşamıştır: 1876, 1885, 1893, 1908, 1914, 1917-21, 1930-32, 1938, 1945-46, 1975, 1982, 1991, 2009 ve 2020. Bu olayların her birinde, küresel kişi başına düşen GSYİH'da bir daralma yaşanmıştır. Bu açıdan tarihi bir dönem olan 1870-1959 dönemi, her on yılda en az bir tane olmak üzere dokuz küresel durgunluğa tanık olmuştur. 1950'lerde ve 1960'larda 1957'de kısa süren Eisenhower Resesyonu dişında küresel bir durgunluk yaşanmazken, sonraki elli yıl neredeyse her on yılda bir küresel durgunluğa tanık olmuştur. IMF tahminlerine göre, Covid-19 durgunluğunun küresel kişi başına GSYİH'de yüzde 6.2'lik bir düşüşü içereceğini, bunun da onu 1945-46'dan bu yana en derin küresel durgunluk ve küresel finansal krizle ilişkili durgunluğun iki katından daha derin hale getireceğini göstermektedir (IMF, 2020: 15).

Yükselen piyasa ve gelişmekte olan ekonomilerin üretimlerinin en az 60 y1l sonra ilk kez 2020 'de daralması beklenmektedir. Mevcut küresel durgunluk, küresel büyüme tahminlerinin 
en az 1990'dan bu yana diğer tüm resesyonlardan daha dik ve hızlı bir şekilde aşağıya çekilmesi bakımından da benzersizdir. Önceki küresel durgunluklarda öngörülen düşüş tahminlerinin kademeli niteliği, tahmincilerin pandeminin evrimi hakkında yeni bilgileri edinmesiyle düşüş tahminlerinin de giderek düşeceğini göstermektedir. Bu nedenle, önümüzdeki aylarda üretim faaliyetlerinin desteklenebilmesi amacıyla ek politika önlemlerine ihtiyaç duyulabilecektir (World Bank, 2020: 13).

Covid-19 salgını, dünya çapında yüksek ve artan sayıda insan maliyetlerine neden olmaktadır. Hayatları korumak ve sağlık bakım sistemlerinin başa çıkmasına izin vermek, virüsün yayılmasını yavaşlatmak için gerekli izolasyon, karantinalar ve yaygın kapanmalar gerektirmektedir. Sağlık krizi bu nedenle ekonomik faaliyet üzerinde ciddi bir etkiye sahip olmaktadır. Pandeminin bir sonucu olarak, küresel ekonominin 2020 'de $\% 3$ oranında keskin bir şekilde, 2007-09 mali krizinden çok daha sert bir şekilde küçülebileceği tahmin edilmektedir (IMF, 2020: vii).

Öte yandan, hükümetler ve şirketler, Covid-19 salgınına zaten oldukça ağır borç yükleriyle girmiştir. Kurumsal bilançolar nihayetinde Covid-19 kaynaklı resesyonlardan ötürü zarar görebilir ve banka bilançolarını finansal krizleri tetikleyebilecek ölçüde zorlayabilir. Bu durum, sermayenin değer kaybetmesine ve büyük istihdam kayıplarına yol açabilecektir (World Bank, 2020: i.9).

Uygulanacak ekonomi politikalarının insanlar, firmalar ve finansal sistem faaliyetlerindeki düşüşün etkisini hafifletmesi gerekecektir. $\mathrm{Bu}$ politikaların kaçınılmaz olarak sert yavaşlamadan kaynaklanabilecek kalıcı etkilerin azaltılması ve pandemi ortadan kalktığında da ekonomik iyileşmenin hızlı bir şekilde başlayabilmesini sağlaması amaçlanmalıdır.

Alınan önlemlere bir örnek olarak belirtilmesi açısından, Avrupa İmar ve Kalkınma Bankası'nın (EBRD) Koronavirüs salgını nedeniyle aldığı önlemler çeşitli Uluslararası Finansal Kuruluşların ve ülkelerin almakta olduğu önlemlere bir özet oluşturmaktadır. EBRD, virüsten kaynaklanan acil tehditle mücadeleye yardımcı olmak amacıyla finansman ve politika desteği sağlamak için mevcut araçları uyarlayıp ölçeklendirmekte ve yeni girişimler geliştirmektedir. En önemlisi, üye ülkeleri virüs sonrası döneme hazırlamaktadır ve sürdürülebilir, adil ve açık pazar ekonomileri inşa edilebilmesi için bugüne kadar başarılmış her şeyin koruma altına alınmasını sağlamaktadır. EBRD, şu anda 2021'in sonuna kadar 21 milyar Euro tutarında destek sağlamaya hazır olduklarını bildirmiştir (EBRD, 2020: 1).

Dünya Bankası ve IMF de benzer biçimde yeni ekonomi paketleri açıklamış ve bütçelerini bu doğrultuda artırdıklarını duyurmuşlardır. Salgın, tüm ülkelere oldukça ağır bir fatura ortaya çıkarmıştır. Gelişmiş, gelişmekte olan, az gelişmiş bütün ülkeler ekonomik büyüklüklerinin izin verdiği ölçüde, pandeminin gidişatına göre çeşitli zamanlarda koşulların gerektirdiği durumlara uygun olarak belirledikleri birden fazla ekonomi paketini açıklamışlardır. Bu paketler stratejik firmalar için kurtarma paketleri, bireylere ve esnafa doğrudan para yardımı, oldukça düşük faizli uzun vadeli kredilerin sağlanması gibi çeşitlilikler göstermektedir.

OECD, tüm önemli çabalara rağmen, rakamların gayet net ve tahminlerin de kasvetli olduğunu vurgulamıştır. İkinci bir enfeksiyon dalgasından kaçınılsa bile, Haziran 2020 OECD Ekonomik Görünümü (OECD Economic Outlook), 2020 için küresel GSYİH'de \%6'lık bir düşüş öngörmüştür. OECD çapında 2019 yılında \%5.4 olan işsizlik oranının 2020'nin sonunda \%9.4 olması beklenmektedir. $\mathrm{Bu}$ tarihi zirvenin ardından ise bir yıl sonra \%7.7 olması beklenmektedir. Kriz, dünya ve OECD ekonomileri üzerinde uzun vadeli bir gölge 764 
oluşturacaktır. 2021 yılına kadar, OECD ekonomilerinin çoğunda kişi başına reel geliri, yaygın ikinci enfeksiyon dalgasının yokluğunda bile 2016 seviyelerine düşmüş olacaktır. OECD'nin tahminlerine göre, 2020'nin sonlarında ikinci bir dalganın tüm OECD ekonomilerini vurduğu "çift vuruş" senaryosunda, 2021'de OECD ekonomisinde kişi başına reel gelir ortalaması 2013 seviyelerine geri dönebilecektir (OECD, 2020a: 3).

Büyük doğal afetler, savaşlar ve mali krizler tipik olarak kalıcı verimlilik kayıplarıyla ilişkilendirilirken, büyük durgunluklar bazen belirli sektörlerde yeni teknolojilerin benimsenmesini teşvik etmiştir. Covid-19, üretimin otomasyonunu ve dijital teknolojilerin daha geniş bir şekilde üretime dahil edilmesini hızlandırabilir. Bu verimlilik kazanımları eşit olmayan bir şekilde dağıtılabilir ve bazı sektörlerde istihdam kayıplarına neden olabilir (Dieppe, 2020: i.9).

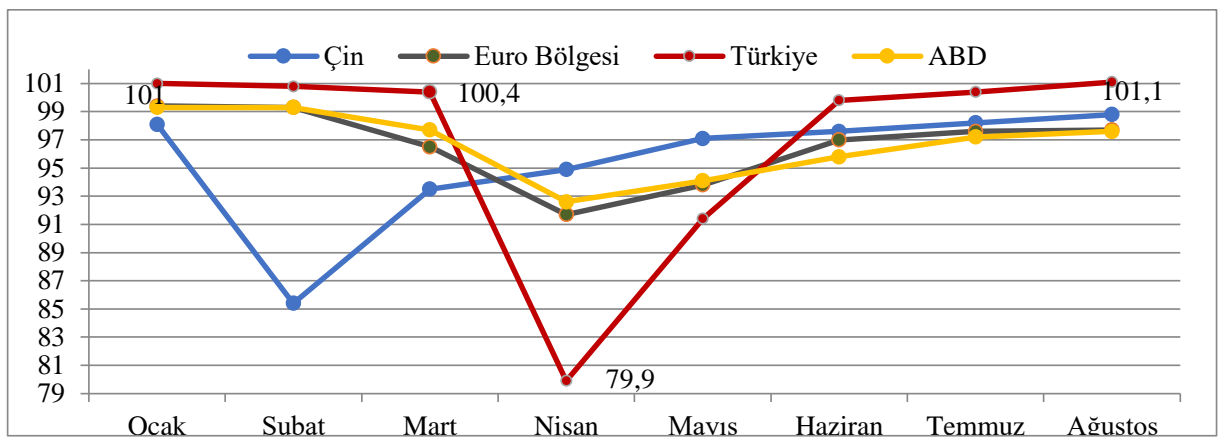

Şekil 2. OECD bileşik göstergeler endeksine göre seçilmiş bazı ekonomilerin Ocak-Ağustos 2020 arasındaki toparlanma eğrisi.

Kaynak: OECD (2020b). Composite leading indicator, https://data.oecd.org/chart/65Lb.

Öte yandan yine OECD’nin bileşik öncü göstergeler bağlamındaki verilerine göre 2020 Ağustos ayına gelindiğinde Covid 19 nedeniyle düşüşe geçen ekonomilerde U tipi ve V tipi olmak üzere bütünleşik bir toparlanma öngörüsü gözlenmiştir. ABD, Çin, Avrupa Birliği ve Türkiye verileri temel alınarak hazırlanmış olan Şekil 2'de söz konusu ekonomilerde Ocak ayı itibarıyla görülen keskin düşüşün Ağustos ayı itibarıyla keskin bir V ve ardından U tipi toparlanma ile devam eden bir eğri gözlenmiştir. Bunların arasında öncü göstergelere göre ekonomik göstergeleri en fazla bozulup en hızlı toparlanan ülkenin Türkiye olduğunun altını çizmek gerekir. Ayrıca Ağustos ayı ile birlikte U tipi olarak süre giden toparlanmanın ne kadar süreceğine yönelik tahminler çeşitlilik göstermektedir.

\subsection{Covid-19 Salgınının Uluslararası Ticarete Etkileri}

Yatırım ve ticaret daha zayıf bir seyir izlemektedir. Pandeminin süresi ve nihayetinde ondan kaynaklanan küresel ekonomik manzara hakkındaki belirsizlik, yatırımları caydırabilecektir. Operasyonların uzun vadeli uygulanabilirliği ve esnekliği ile ilgili endişeler, küresel değer zincirlerinden geri çekilmeye yol açabilir — bu da uluslararası teknoloji aktarımı için önemli bir kanalı tıkayabilir — ve genellikle bu tür üretim süreçleriyle ilgili olan yabancı yatırımları caydırabilir (Dieppe, 2020: i.9). 


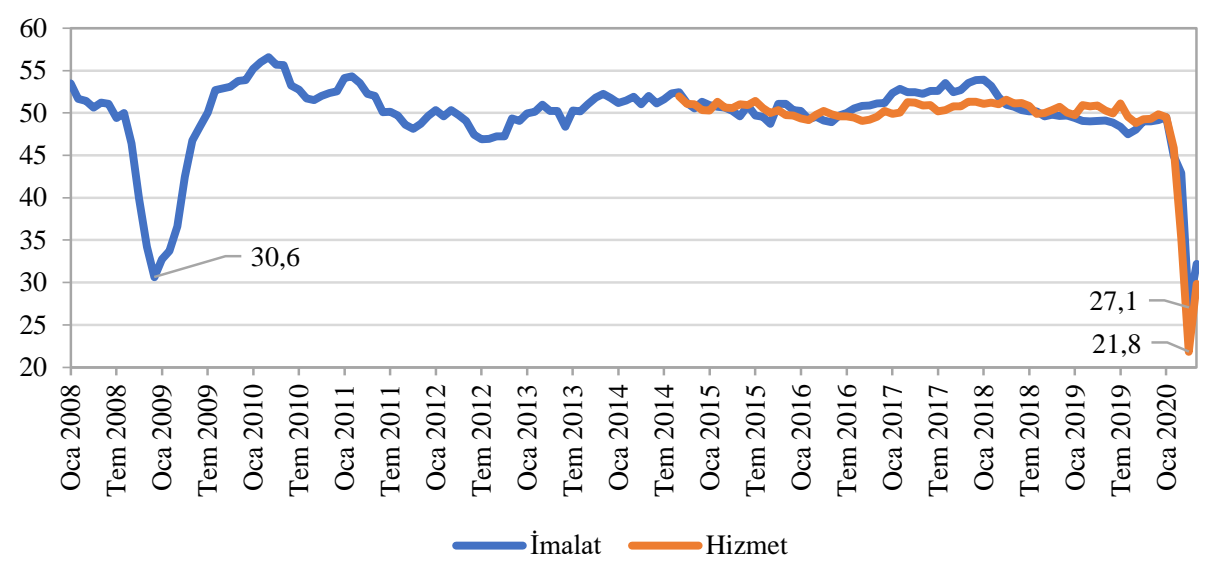

Şekil 3. Küresel PMI yeni ihracat siparişleri endeksleri

Ocak 2010 - Mayıs 2020 (İndeks, 50'lik bir taban çizgisine göredir). Not: 50'den büyük değerler genişlemeyi gösterirken 50'den küçük değerler daralmayı göstermektedir.

Kaynak: WTO. (2020). World Trade Statistical Review 2020.

Satın alma yöneticileri endeksi (PMI) verilerine bağlı yeni ihracat siparişleri incelendiğinde küresel salgına bağlı olarak imalat ve hizmet sektöründeki belirgin düşüş gözlenebilmektedir. Şekil 3'te de görüldüğü gibi 2007-2009 küresel krizinde 30.6'ya gerilemiş olan imalata yönelik PMI yeni ihracat siparişleri endeksinin Ocak 2010'daki toparlanışından sonra ticaret savaşlarının etkisiyle az bir düşüş eğiliminden sonra Ocak 2020'dan itibaren sert düşüşe geçtiği ve Nisan 2020'de 27.1 seviyelerine gerilediği görülmektedir. Aynı ayda, hizmetlerdeki yeni ihracat siparişleri, 50'lik bir taban çizgisine göre ölçüldüğünde, 21.7'ye düşmüştür. Mayıs 2020 'den itibaren göreli bir toparlanma seyri gözlenmektedir. Mayıs 2020'de imalat ve hizmet ihracat sipariş endeksleri sırasıyla 32.2 ve 29.8 'e yükseldi, ancak trendin önemli ölçüde altında kalmıştır. PMI endekslerindeki değişimler, fiili ticaret akışlarındaki değişiklikleri önceden haber verme eğiliminde olup, ticaret seviyelerinin Haziran ayında toparlanmaya başlamadan önce Nisan veya Mayıs 2020 'de dibe vurabileceğini düşündürmektedir. Henüz içinde bulunduğumuz salgın koşullarında bu seyrin karantinalara, iş bırakmalara veya yeni normallere dönüşlere bağlı olarak değişebileceği anlaşılmaktadır. 


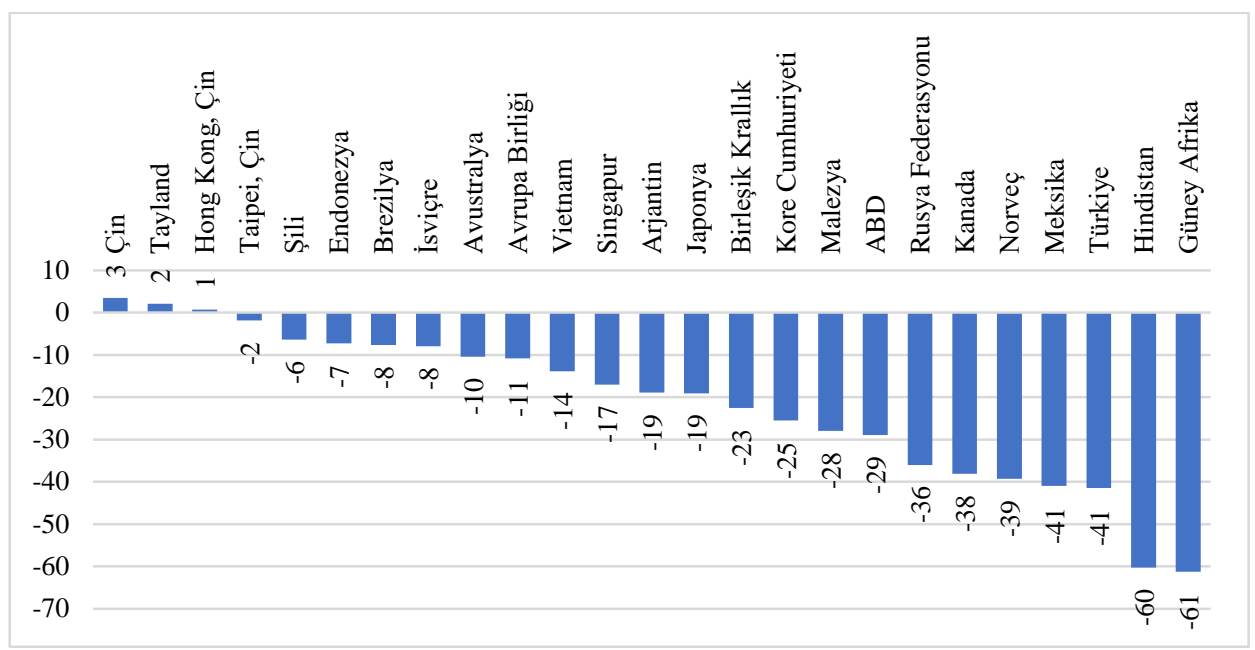

Şekil 4. Seçilmiş önde gelen ticaret ülkelerinin ürün ihracatı, Nisan 2020, Yıllık yüzde değişim. Kaynak: WTO. (2020). World Trade Statistical Review 2020.

Şekil 4'te de görüldüğü gibi, emtia ihracat1, ekonomilerin çoğunda Nisan 2020'de bir önceki yıla göre keskin bir düşüş göstermiştir. Önde gelen ticaret ülkelerinin emtia ihracatında Nisan 2020'de (y1llık değişim) düşüşler yüzde -2'den (Çin Taypesi) yüzde -61'e (Güney Afrika) kadar değişmiştir. Şekilde belirtilen mevcut ABD doları cinsinden aylık emtia ticareti istatistikleri, hacim bazında üç aylık istatistiklere göre daha günceldir. Bazı Asya ekonomileri ihracattaki düşüşlerden kaçınsa da (Nisan 2020'de), ithalat büyümeleri negatif kalmıştır. Örneğin, Nisan 2020'de Çin ve Tayland'ın ithalatı sırasıyla yüzde 14 ve yüzde 17 düşmüştür (WTO, 2020: 30).

Sonuç olarak Uluslararası Ticaret, Covid-19 pandemisinin beraberinde getirdiği resesyondan büyük oranda negatif olarak etkilenmiştir. Mart 2021 ayında bulunduğumuz şu günlerde pandeminin seyrine bağlı olarak bazı ülkelerde karantina önlemleri azaltılırken, bazı ülkelerde ise sıkı karantina önlemleri sürmektedir. Yürütülmekte olan aşılama çalışmalarının olumlu etkisi arttıkça karantina önlemlerinin daha hızlı azaltılması ve üretimin artması beklenmektedir. İçinde bulunduğumuz günlerde bunun için halen erken olduğu görülmektedir. Tahminler, Haziran 2021'den itibaren aşılama çalışmalarındaki ilerlemelere bağlı olarak tam kapasite üretime yavaş yavaş dönülebileceğine ve uluslararası ticaretin de belirli bir oranda toparlanabileceğine işaret etmektedir. Ayrıca tahminler, karantina önlemlerine uyulmaması nedeniyle küresel ölçekte salgının birkaç dalga daha devam etmesi halinde küresel ekonominin ve uluslararası ticaretin normal seyrine dönüş süresinin de uzayabileceğini göstermektedir. Karantinaların kaldırılmasına bağlı olarak belirli bir seviyede bir toparlanma olsa da uluslararası ticaretin normal seyrine dönebilmesi için salgının tüm dünyada belirli bir oranda gerilemesi gerekecektir.

\section{BULGULAR VE SONUÇ}

14. yüzyıldaki veba'dan, 15. yüzyıldaki suçiçeği salgınına, İspanyol Gribinden, 1957 Asya gribine kadar gerçekleşmiş olan birçok salgının dünya uluslarına olan etkileri ve onların reaksiyonları oldukça değerli dersler barındırmaktadır. Tarihteki kayıtlar, büyüklük olarak ne kadar farklı olsa da geçmişteki dünya ekonomisinin salgınlar karşısındaki performansının 
ortaya koyduğu göstergelerle, şimdi koronavirüs salgınıyla veya sonraki salgınlarla mücadelede köklü bilgi ve kılavuzluk sağlamaktadır.

Çalışmada Covid-19 dışında incelenmiş olan diğer salgınlar da göz önünde bulundurulduğunda, uluslararası ticaret ve ekonomik sonuçlar bağlamında ortak özellikler gözlenmiştir. $\mathrm{Bu}$ ortak özelliklerin odak noktasının küresel salgınların küresel çapta bir resesyona ve bazı durumlarda da uluslararası ticaretin tamamen durmasına neden olduğu belirtilebilir. $\mathrm{Bu}$ sorunların derinleşmesinin altında yatan temel nedenin ise önde gelen ekonomilerin anlaşmazlıklarını belirli bir ölçüde giderememiş olmalarından ötürü yaşanan küresel işbirliksizliği olduğu bulgusuna ulaşılmıştır.

Geçmişte yaşanmış olan birçok salgının aksine Covid-19 salgını sırasında her bir dalga sonucunda V tipi toparlanmanın çok az ülke için geçerli olduğu görülmüştür. Genellikle gelişmiş ülkelerin U tipi toparlanmaya sahip olduğu, az gelişmiş ve gelişmekte olan ülkelerdeki koşulların ise her salgın dalgasında V tipi toparlanmaya daha müsait olduğu gözlenmiştir. Bundaki ana etkenin gelişmiş ülkelerdeki halkların hükümetlerinin aldığı karantina kararlarına uymamasının yeni dalgaları beraberinde getirmesi olarak değerlendirilebilir. Her yeni dalgayla birlikte karantina önlemleri devam ettikçe üretim büyük ölçüde etkilenmekte ve uluslararası ticaretteki payına olumsuz olarak yansımaktadır. Grafiklerde de görüldüğü gibi gelişmekte olan ülkelerdeki toparlanma, karantina kararlarına uyulduğu ölçüde V tipi şeklinde olmaktadır.

Uluslararası Ticaret, Covid-19 pandemisinin beraberinde getirdiği resesyondan büyük oranda negatif olarak etkilenmiştir. Mart 2021 ayında bulunduğumuz şu günlerde pandeminin seyrine bağlı olarak bazı ülkelerde karantina önlemleri azaltılırken, bazı ülkelerde ise sıkı karantina önlemleri sürmektedir. Yürütülmekte olan aşılama çalışmalarının olumlu etkisi arttıkça karantina önlemlerinin daha hızlı azaltılması ve üretimin artması beklenmektedir. İçinde bulunduğumuz günlerde bunun için halen erken olduğu görülmektedir. Tahminler, Haziran 2021 'den itibaren aşılama çalışmalarındaki ilerlemelere bağlı olarak tam kapasite üretime yavaş yavaş dönülebileceğine ve uluslararası ticaretin de belirli bir oranda toparlanabileceğine işaret etmektedir. Ayrıca tahminler, karantina önlemlerine uyulmaması nedeniyle küresel ölçekte salgının birkaç dalga daha devam etmesi halinde küresel ekonominin ve uluslararası ticaretin normal seyrine dönüş süresinin de uzayabileceğini göstermektedir. Karantinaların kaldırılmasına bağlı olarak belirli bir seviyede bir toparlanma olsa da uluslararası ticaretin normal seyrine dönebilmesi için salgının tüm dünyada belirli bir oranda gerilemesi gerekecektir.

Çalışmada elde edilen bulgular 1şı̆̆ında bakıldığında, günümüzde yaşanmakta olan bu küresel salgın sırasında veya sonrasında küresel ekonominin ve uluslararası ticaretin kısa vadeli acil çözümlere ihtiyaç duyuyor olmasının, daha sürdürülebilir uzun vadeli çözümlerin de ortaya konulması gerekliliğinin göz ardı edilmesine neden olmaması gerektiği sonucuna ulaşılmaktadır. Bu çalışma, sürdürülebilir küresel ekonomi ve sürdürülebilir uluslararası ticaret için küresel işbirliğinin önemine dikkat çekmeyi amaçlamıştır. Önde gelen ülkelerin anlaşmazlıklarını gidermesi küresel refahın en temel bileşenlerindendir. Önde gelen ekonomiler anlaşmazlıklarını bir ölçüde azaltabildiği takdirde küresel ekonominin ve uluslararası ticaretin en zor şartlarda dahi sürdürülebilmesine olanak tanınabilecek anlaşmalara ve çözümlere varılabilecektir. Bu çözümlerin başında her ulusun öz tarımsal üretiminin ve gıda egemenliğinin güvence altına alınmasının olanaklı hale getirilmesi önemli bir yer tutmaktadır.

\section{KAYNAKÇA}


ACEMOĞLU, D. \& ROBINSON, J.A. (2014). Ulusların Düşüşü, Güç, Zenginlik ve Yoksulluğun Kökenleri, Çev. Faruk Rasim Velioğlu, Doğan Egmont Yayıncılık ve Yapımcılık Tic. A.Ş.: İstanbul).

ALPAGO, H. \& ODUNCU, D. (2020). 'Koronavirüs Salgınının Sosyoekonomik Sonuçları', IBAD Sosyal Bilimler Dergisi (8). 99-114. 10.21733/ibad.716444.

BELL, C. \& LEWIS, M. (2005). The Economic Implications of Epidemics Old and New. SSRN Electronic Journal. 10.2139/ssrn.1112799, pp. 137-174.

BARQUET N. \& DOMINGO, P. (1997). 'Smallpox: The Triumph over the Most Terrible of the Ministers of Death', Annals of Internal Medicine, 127 (8), pp. 635-642.

BRAINERD, E. \& SIEGLER, M.V. (2003). The economic effects of the 1918 influenza epidemic. CEPR Discussion Paper No. 379, Centre for Economic Policy Research.

COOK, N. (2002). Sickness, Starvation, and Death in Early Hispaniola. Journal of Interdisciplinary History - J INTERDISCIPL HIST. 32. 349-386. 10.1162/002219502753364173.

DAVILA, B. E. (2018). 'En el centenario de la gripe española: un estado de la cuestión' Revista de Demografía Histórica, ISSN 1696-702X, 36 (1), 2018, pp. 17-42.

DIEPPE, A. (2020). Global Productivity: Trends, Drivers, and Policies. Advance Edition. Washington, DC: World Bank. License: Creative Commons Attribution CC BY 3.0 IGO.

DONALDSON, D. \& KENISTON, D. (2016). Dynamics of a Malthusian Economy: India in the Aftermath of the 1918 Influenza. Chicago: Becker Friedman Institute for Research in Economics, University of Chicago.

DOREL, F. (2006). La thèse du "génocide indien": guerre de position entre science et mémoire. Amnis: Revue de Civilisation Contemporaine de l'Université de Bretagne Occidentale, ISSN 1764-7193, No. 6, 2006 (Ejemplar dedicado a: La Guerra y sus víctimas (EuropaAmérica Siglo XIX-Siglo XXI)). 10.4000/amnis.908.

EBRD. (2020). The EBRD's coronavirus Solidarity Package, https://www.ebrd.com/what-wedo/coronavirus-solidarity, Erişim Tarihi: 09.08.2020.

FRANKE, C. (2016). The Black Death, an Unforeseen Exchange: Europe's Encounter with Pandemic Sparked an Age of Exploration, Washington Technology Magnet School, St. Paul), 2nd place, 2016 National History Day competition.

FURUSE, Y., SUZUKI, A. and OSHITANI, H. (2010). "Origin of the Measles Virus: Divergence from Rinderpest Virus Between the 11th and 12th Centuries," Virology 7 (2010), pp. 52-55.

GARRETT, T. (2007). Economic Effects of the 1918 Influenza Pandemic Implications for a Modern-day Pandemic. Working paper CA0721.

GENÇ, Ö. (2011). Kara Ölüm: 1348 Veba Salgını Ve Ortaçağ Avrupa'sına Etkileri, Tarih Okulu, Mayıs - Ağustos 2011, sayı: X, ss. 123-150. 
HÄGGQVİST, H. (2019). Wartime and Post-war Economies (Sweden), in: 1914-1918-online. International Encyclopedia of the First World War, ed. by Ute Daniel, Peter Gatrell, Oliver Janz, Heather Jones, Jennifer Keene, Alan Kramer, and Bill Nasson, issued by Freie Universität Berlin, Berlin 2019-09-18. DOI: 10.15463/ie1418.11402.

HENIGE, D. (1978). On the Contact Population of Hispaniola: History as Higher Mathematics. Hispanic American Historical Review 1 May 1978; 58 (2): 217-237. doi: https://doi.org/10.1215/00182168-58.2.217.

IMF. (2019). Global Financial Stability Report: Lower for Longer, International Monetary Fund, Washington, DC, October.

JAMES, S. \& SARGENT, T. (2007). The Economic Impact of an Influenza Pandemic, Department of Finance of Canada Working Paper 2007/4.

JORDÀ, Ò., SINGH, S. R. \& TAYLOR, A.M. (2020). Longer-Run Economic Consequences of Pandemics, Federal Reserve Bank of San Francisco Working Paper 2020-09.

MALANIMA P. (2012). 'The economic consequences of the Black Death', L'impatto della "Peste Antonina", Ed. Elio Lo Cascio, (Edipuglia: Bari, 2012), pp. 311-328.

NUNN, N., QIAN, N. (2010). 'The Columbian Exchange: A History of Disease, Food, and Ideas', Journal of Economic Perspectives, 24 (2), Spring 2010, pp. 163-188.

OBRIZAN, M., KARLSSON, M., \& MATVIEIEV, M. (2020). The Macroeconomic Impact of the 1918-19 Influenza Pandemic in Sweden, MPRA Paper 98910, University Library of Munich, Germany.

OECD. (2020a). OECD Employment Outlook 2020: Worker Security and the COVID-19 Crisis, OECD Publishing, Paris, https://doi.org/10.1787/1686c758-en.

OECD. (2020b). Composite leading indicator, https://data.oecd.org/chart/65Lb, Erişim Tarihi: 17.09.2020.

OXFORD, J., SEFTON, A., JACKSON, R., INNES, W., DANIELS, R., \& JOHNSON, N. (2001). Early herald wave outbreaks of influenza in 1916 prior to the pandemic of 1918. International Congress Series. 1219. 10.1016/S0531-5131(01)00336-3, pp. 155161.

ÖZDEN, K. \& ÖZMAT, M. (2014) 'Salgın ve Kent: 1347 Veba Salgınının Avrupa'da Sosyal, Politik ve Ekonomik Sonuçları’, İdealkent, sayı: 12 (Nisan 2014), ss. 60-87.

PAMUK, Ş. (2007). "The Black Death and the origins of the 'Great Divergence"”, European Review of Economic History, pp. 289-317.

PBS. (2020). A science odyssey: people and discoveries. Worldwide flu pandemic strikes, 1918-1919. Erişilebilir: http://www.pbs.org/wgbh/aso/databank/entries/dm18fl.html. Erişim tarihi: 17.07.2020.

PIRENNE, H. (2009). Ortaçă̆ Avrupa'sının Ekonomik ve Sosyal Tarihi, Çev: Uygur Kocabaşoğlu, (İletişim Yayınları: İstanbul, 2009).

RICHARDS, A. (2020). How Low Can It Go? Asian Flu of 1957-58 Foretells “Recession” in 2020, Alambic Investment Management, L.P. March 2020. 
ROGERS, K. (2020). 1957 flu pandemic, Encyclopaedia Britannica Online. https://www.britannica.com/event/1957-flu-pandemic, Erişim tarihi: 23 Temmuz 2020.

SAUNDERS-HASTINGS, P. R., \& KREWSKI, D. (2016). Reviewing the History of Pandemic Influenza: Understanding Patterns of Emergence and Transmission. Pathogens (Basel, Switzerland), 5(4), 66.

STEPEK, J. (2020). What Can The 1957 Stockmarket Crash Teach Us About The Coronavirus Crisis?, $\quad$ MoneyWeek, $\quad 11 \quad$ April 2020. https://moneyweek.com/investments/stockmarkets/601152/what-can-the-1957stockmarket-crash-teach-us-about-the-coronavirus, Erişim Tarihi: 26.07.2020.

TABARROK, A. (2020). The Forgotten 1957 Pandemic and Recession, Marginal REVOLUTION, March 24, 2020, https://marginalrevolution.com/marginalrevolution/2020/03/the-forgotten-1957pandemic-and-recession.html, Erişim Tarihi: 26.07.2020.

TRILlA, A., TRILlA, G., \& DAER, C. (2008). The 1918 “"Spanish Flu' in Spain”, Clinical infectious diseases: an official publication of the Infectious Diseases Society of America. 47. 10.1086/590567, pp. 668-73.

TÜBA. (2020). Covid-19 Pandemi Değerlendirme Raporu, Türkiye Bilimler Akademisi Yayınları, TÜBA Raporları No: 34. 17 Nisan 2020, Ankara.

VOLLMER, S. \& WÓJCIK, J. (2017). The long-term consequences of the global 1918 influenza pandemic: A systematic analysis of 117 IPUMS international census data sets. PGDA Working Paper No. 141.

World Bank. (2020). Global Economic Prospects, June 2020. Washington, DC: World Bank. DOI: 10.1596/978-1-4648-1553-9.

WTO. (2020). World Trade Statistical Review 2020, The World Trade Organization.

YONEYAMA, T. \& KRISHNAMOORTHY, M. (2010). Influence of the Cold War Upon Influenza Pandemic of 1957-1958. Proceedings 6th IEEE International Conference on E-Science (E-Science 2010). 12. 10.1109/eScience.2010.25. 